\title{
Possible Processes for Origin of First Chemoheterotrophic Microorganisms with Modeling of Physiological Processes of Bacterium Bacillus Subtilis as a Model System in ${ }^{2} \mathrm{H}_{2} \mathrm{O}$
}

\author{
Ignat Ignatov ${ }^{*}$ and Oleg Mosin ${ }^{2}$ \\ 1. DSc, Professor, Scientific Research Center of Medical Biophysics (SRCMB), \\ N. Kopernik Street, 32, Sofia 1111, Bulgaria \\ 2. PhD (Chemistry), Biotechnology Department, Moscow State University of Applied Biotechnology, \\ Talalikhina Street, 33, Moscow 109316, Russian Federation
}

\begin{abstract}
In this research we studied possible processes for origin of first chemoheterotrophic microorganisms with modeling of physiological processes of a Gram-positive chemoheterotrophic bacterium Bacillus subtilis, producer of purine ribonucleoside inosine as a model system in heavy water. The physiological influence of deuterium on the chemoheterotrophic bacterium B. subtilis was studied on a heavy water (HW) medium with a maximal concentration of ${ }^{2} \mathrm{H}_{2} \mathrm{O}\left(89-90\right.$ atom $\left.\%{ }^{2} \mathrm{H}\right)$. Also various suitable samples of hot mineral water and sea water derived from different sources of Bulgaria were investigated using IR- and DENS-spectroscopy. It was shown that hot alkaline mineral water with temperature from $+65{ }^{\circ} \mathrm{C}$ to $+95{ }^{\circ} \mathrm{C}$ and $\mathrm{pH}$ value from 9 to 11 is more suitable for the origination of first organic forms than other analyzed water samples. There were discussed the reactions of condensation and dehydration occurring in alkaline aqueous solutions at $\mathrm{t}=+65-95^{\circ} \mathrm{C}$ and $\mathrm{pH}=$ $9-10$, resulting in synthesis from separate molecules the larger organic molecules as short polipeptides and pyrines, as well as the possible mechanisms of the deuterium accumulation in form of HDO in hot water. The metabolism of the bacterium $B$. subtilis and the resistance to deuterium was also analyzed on an evolutionary level taking into account the hydrological conditions of primodial hydrosphere and the presence of $\mathrm{H}^{2} \mathrm{HO}$, as well as the qualitative and quantitative composition of the cellular protein, amino acids and carbohydrates on media with maximum deuterium content. We demonstrated on the example of chemoheterotrophic bacteria that first microorganisms might have been originated in hot mineral water with $\mathrm{Ca}^{2+}$ at $\mathrm{t}=+65-95^{\circ} \mathrm{C}$ and $\mathrm{pH}=9-11$ that is more suitable for maintenance and origin of life than other analyzed water samples.
\end{abstract}

Keywords: heavy water, glycolysis, purines, amino acids, Bacillus subtilis, hot mineral water, origin of life and living mater

\section{Introduction}

One of the most interesting biological phenomena is the ability of some microorganisms to grow in heavy water (HW) media in which all hydrogen atoms are replaced with deuterium $\left({ }^{2} \mathrm{H}\right)$ (Mosin et al., 2000). The chemical structure of the ${ }^{2} \mathrm{H}_{2} \mathrm{O}$ molecule is analogous to that one for $\mathrm{H}_{2} \mathrm{O}$, with small differences in the length of the covalent $\mathrm{H}-\mathrm{O}$ bonds and the angles between them. The molecular mass of ${ }^{2} \mathrm{H}_{2} \mathrm{O}$ exceeds on $10 \%$ that one for $\mathrm{H}_{2} \mathrm{O}$. That difference stipulates the isotopic effects, which may be sufficiently big for $\mathrm{H} /{ }^{2} \mathrm{H}$ pair (Lobishev \& Kalinichenko, 1978). As a result, physical-chemical properties of ${ }^{2} \mathrm{H}_{2} \mathrm{O}$ differ from $\mathrm{H}_{2} \mathrm{O}:{ }^{2} \mathrm{H}_{2} \mathrm{O}$ boils at $+101.44{ }^{0} \mathrm{C}$, freezes at $+3.82{ }^{\circ} \mathrm{C}$, has maximal density at $+11.2{ }^{\circ} \mathrm{C}\left(1.106 \mathrm{~g} / \mathrm{cm}^{3}\right)$. The chemical reactions in ${ }^{2} \mathrm{H}_{2} \mathrm{O}$ are somehow slower compared to $\mathrm{H}_{2} \mathrm{O} .{ }^{2} \mathrm{H}_{2} \mathrm{O}$ is less ionized, the dissociation constant is smaller, and the solubility of the organic and inorganic substances in ${ }^{2} \mathrm{H}_{2} \mathrm{O}$ is smaller compared to these ones in $\mathrm{H}_{2} \mathrm{O}$. Due to isotopic effects the hydrogen bonds with the participation of deuterium are slightly stronger than those ones formed of hydrogen. According to the theory of chemical bond, breaking up of covalent $\mathrm{H}-\mathrm{O}$-bonds can occur faster, than ${ }^{2} \mathrm{H}-\mathrm{O}$-bonds, mobility of ${ }^{2} \mathrm{H}_{3} \mathrm{O}^{+}$ion is lower on $28.5 \%$ than $\mathrm{H}_{3} \mathrm{O}^{+}$ion, and $\mathrm{O}^{2} \mathrm{H}^{-}$ion - on $39.8 \%$ than $\mathrm{OH}^{-}$ion. The maximum kinetic isotopic effect, which can be observed at ordinary temperatures in chemical reactions leading to rupture of bonds involving $\mathrm{H}$ and ${ }^{2} \mathrm{H}$ lies in the range of 4 to 6 for $\mathrm{C}-\mathrm{H}$ versus $\mathrm{C}-{ }^{2} \mathrm{H}, \mathrm{N}-\mathrm{H}$ versus $\mathrm{N}-{ }^{2} \mathrm{H}$, and $\mathrm{O}-\mathrm{H}$ versus $\mathrm{O}-{ }^{2} \mathrm{H}-$ bonds (Cleland et al., 1976).

These chemical-physical factors lead to slowing down in the rates of enzymatic reactions in ${ }^{2} \mathrm{H}_{2} \mathrm{O}$ (Cleland, 1976). However, there are also such reactions which rates in ${ }^{2} \mathrm{H}_{2} \mathrm{O}$ are higher than in $\mathrm{H}_{2} \mathrm{O}$. In general these reactions are catalyzed by ${ }^{2} \mathrm{H}_{3} \mathrm{O}^{+}$or $\mathrm{H}_{3} \mathrm{O}^{+}$ions or $\mathrm{O}^{2} \mathrm{H}^{-}$and $\mathrm{OH}^{-}$ions. The substitution of ${ }^{1} \mathrm{H}$ with ${ }^{2} \mathrm{H}$ affects the stability and geometry of hydrogen bonds in an apparently rather complex way and may through the changes in the hydrogen bond zero-point vibration energies, alter the conformational dynamics of hydrogen (deuterium)- 
bonded structures of DNA and proteins in ${ }^{2} \mathrm{H}_{2} \mathrm{O}$. It may cause disturbances in the DNA-synthesis during mitosis, leading to permanent changes on DNA structure and consequently on cell genotype (Lamprecht et al., 1989). Isotopic effects of deuterium, which would occur in macromolecules of even a small difference between hydrogen and deuterium, would certainly have the effect upon the structure. The sensitivity of enzyme function to the structure and the sensitivity of nucleic acid function (genetic and mitotic) would lead to a noticeable effect on the metabolic pathways and reproductive behavior of an organism in the presence of ${ }^{2} \mathrm{H}_{2} \mathrm{O}$ (Török et al., 2010). And next, the changes in dissociation constants of DNA and protein ionizable groups when transferring the macromolecule from $\mathrm{H}_{2} \mathrm{O}$ into ${ }^{2} \mathrm{H}_{2} \mathrm{O}$ may perturb the charge state of the DNA and protein molecules.

The average ratio of ${ }^{2} \mathrm{H} /{ }^{1} \mathrm{H}$ in nature makes up approximately 1:5700 (Lis et al., 2008). In natural waters, the deuterium is distributed irregularly: from $0.02-0.03 \mathrm{~mol} \%$ for river water and sea water, to $0.015 \mathrm{~mol} \%$ for water of Antarctic ice - the most purified from deuterium natural water containing in 1.5 times less deuterium than that of seawater. According to the international SMOW standard isotopic shifts for ${ }^{2} \mathrm{H}$ and ${ }^{18} \mathrm{O}$ in sea water: ${ }^{2} \mathrm{H} /{ }^{1} \mathrm{H}=(155.76 \pm 0.05) \cdot 10^{-6}(155.76 \mathrm{ppm})$ and ${ }^{18} \mathrm{O} /{ }^{16} \mathrm{O}=(2005.20 \pm 0.45) \cdot 10^{-6}(2005 \mathrm{ppm})$. For the SLAP standard isotopic shifts for ${ }^{2} \mathrm{H}$ and ${ }^{18} \mathrm{O}$ in seawater make up ${ }^{2} \mathrm{H} /{ }^{1} \mathrm{H}=89 \cdot 10^{-6}(89 \mathrm{ppm})$ and for a pair of ${ }^{18} \mathrm{O} /{ }^{16} \mathrm{O}=1894 \cdot 10^{-6}$ (1894 ppm). In surface waters, the ratio ${ }^{2} \mathrm{H} /{ }^{1} \mathrm{H}=\sim(1.32-1.51) \cdot 10^{-4}$, while in the coastal seawater $-\sim(1.55-$ 1.56) $10^{-4}$. The natural waters of CIS countries are characterized by negative deviations from the SMOW standard to (1.0-1.5) $10^{-5}$, in some places up to $(6.0-6.7) \cdot 10^{-5}$, but however there are also observed positive deviations at $2.010^{-5}$. In mixtures of ${ }^{2} \mathrm{H}_{2} \mathrm{O}$ with $\mathrm{H}_{2} \mathrm{O}$ it is occurred with high speed the isotopic exchange with the formation of semi-heavy water $\left(\mathrm{H}^{2} \mathrm{HO}\right):{ }^{2} \mathrm{H}_{2} \mathrm{O}+\mathrm{H}_{2} \mathrm{O}=\mathrm{H}^{2} \mathrm{HO}$. For this reason deuterium presents in smaller content in aqueous solutions in form of $\mathrm{H}^{2} \mathrm{HO}$, while in the higher content - in form of ${ }^{2} \mathrm{H}_{2} \mathrm{O}$.

For a long time it was considered that heavy water is incompatible with life. Experiments with the cultivation of cells of different organisms in ${ }^{2} \mathrm{H}_{2} \mathrm{O}$ show toxic influence of deuterium. The high concentrations of ${ }^{2} \mathrm{H}_{2} \mathrm{O}$ lead to the slowing down the cellular metabolism, mitotic inhibition in the prophase stage and in some cases - somatic mutations (Thomson, 1960). Experiments show that ${ }^{2} \mathrm{H}_{2} \mathrm{O}$ influences negatively the different organisms. This is observed even while using natural water with an increased content of ${ }^{2} \mathrm{H}_{2} \mathrm{O}$ or $\mathrm{H}^{2} \mathrm{HO}$ (Bild et al., 2004). Bacteria can endure up to $90 \%(\mathrm{v} / \mathrm{v}){ }^{2} \mathrm{H}_{2} \mathrm{O}$ (Mosin \& Ignatov, 2012), plant cells can develop normally up to - 75\% (v/v) ${ }^{2} \mathrm{H}_{2} \mathrm{O}$ (Kushner et al., 1999), and animal cells - up to not more than $35 \%$ (v/v) ${ }^{2} \mathrm{H}_{2} \mathrm{O}$ (Daboll et al., 1962). The decrease of the deuterium content in water up to $25 \%(\mathrm{v} / \mathrm{v})$ of the physiological level stimulates the cellular metabolism (Sinyak et al., 2003).

Our studies indicated that the ability of adaptation to ${ }^{2} \mathrm{H}_{2} \mathrm{O}$ for different taxonomic groups of microorganisms is different, and stipulated by taxonomic affiliation, metabolic characteristics, pathways of assimilation of substrates, as well as by evolutionary niche occupied by the object (Mosin et al., 2013). Thus, the lower the level of evolutionary organization of the organism, the easier it adapted to the presence of deuterium in growth media. Thus, most primitive in evolutionary terms (cell membrane structure, cell organization, resistance to environmental factors) of the studied objects are photo-organotrophic halobacteria related to archaebacteria, standing apart from both prokaryotic and eukaryotic microorganisms, exhibiting increased resistance to ${ }^{2} \mathrm{H}_{2} \mathrm{O}$ and practically needed no adaptation to ${ }^{2} \mathrm{H}_{2} \mathrm{O}$, contrary to green algae, which, being eukaryotes, are the more difficult adapted to $\mathrm{D}_{2} \mathrm{O}$ and, therefore, exhibit inhibition of growth at 70-75\% (v/v) $\mathrm{D}_{2} \mathrm{O}$.

At placing a cell onto ${ }^{2} \mathrm{H}_{2} \mathrm{O}$-media lacking protons, not only ${ }^{2} \mathrm{H}_{2} \mathrm{O}$ is removed from a cell due to isotopic $\left({ }^{1} \mathrm{H}-{ }^{2} \mathrm{H}\right)$ exchange, but also there are occurred a rapid isotopic $\left({ }^{1} \mathrm{H}-{ }^{2} \mathrm{H}\right)$ exchange in hydroxyl $(-\mathrm{OH})$, sulfohydryl $(-\mathrm{SH})$ and amino $\left(-\mathrm{NH}_{2}\right)$ groups in all molecules of organic substances, including proteins, nucleic acids, carbohydrates and lipids. It is known, that in these conditions only covalent $\mathrm{C}-\mathrm{H}$ bond is not exposed to isotopic $\left({ }^{1} \mathrm{H}-{ }^{2} \mathrm{H}\right)$ exchange and, thereof only molecules with bonds such as $\mathrm{C}^{-2} \mathrm{H}$ can be synthesized de novo (Mosin, 1996; Mosin \& Ignatov, 2012a). Depending on the position of the deuterium atom in the molecule, there are distinguished primary and secondary isotopic effects mediated by intermolecular interactions. In this aspect, the most important for the structure of macromolecules are dynamic short-lived hydrogen (deuterium) bonds formed between the electron deficient ${ }^{1} \mathrm{H}\left({ }^{2} \mathrm{H}\right)$ atoms and adjacent electronegative $\mathrm{O}, \mathrm{C}, \mathrm{N}, \mathrm{S}$ - heteroatoms in the molecules, acting as acceptors of H-bond (Ignatov \& Mosin, 2013a). The hydrogen bond, based on weak electrostatic forces, donor-acceptor interactions with charge-transfer and intermolecular van der Waals forces, is of the vital importance in the chemistry of intermolecular interactions and maintaining the spatial structure of macromolecules in aqueous solutions (Ignatov \& Mosin, 2013b).

This study is a continuation of our research for studying the possible processes for origin of first organic forms of life in various waters with varying content of deuterium. The content of deuterium in hot mineral water may be increased due to the physical chemical processes of the deuterium accumulation. It can be presumed that primary water might contain more deuterium at early stages of evolution of first living structures, and deuterium was distributed non-uniformly in the hydrosphere and atmosphere (Ignatov \& Mosin, 2012). The primary reductive atmosphere of the Earth consisted basically of gas mixture $\mathrm{CO}, \mathrm{H}_{2}, \mathrm{~N}_{2}, \mathrm{NH}_{3}, \mathrm{CH}_{4}$, lacked $\mathrm{O}_{2}-\mathrm{O}_{3}$ layer protecting the Earth surface from rigid short-wave solar radiation carrying huge energy capable to cause radiolysis and photolysis of water. The processes accompanying accumulation of deuterium in the hydrosphere 
are solar radiation, volcanic geothermal processes and electric discharges in the atmosphere. These natural processes could lead to the enrichment of the hydrosphere by deuterium in the form of $\mathrm{H}^{2} \mathrm{HO}$ which evaporates more slowly than $\mathrm{H}_{2} \mathrm{O}$, and condenses faster. If this is true, this is a significant fact regarding thermal stability of deuterated macromolecules in the preservation of life under thermal conditions, because chemical bonds with participation of deuterium are somewhat stronger than those ones formed of hydrogen.

The object for study relate to different taxonomic groups of organisms having a chemoheterotrophic pathway of assimilation of carbon substrates as glucose via glycolysis. It is believed that the initial life forms on Earth had probably existed as chemoheterotrophic bacteria that received food and energy from organic substrates (Baleux, 1977). That is why the chemoheterotrophic bacterium Bacillus subtilis was chosen as a model for our studies.

The purpose of our research was studying the influence of deuterium on metabolic pathways of B. subtilis applicable to possible processes for origin of life and living matter.

\section{Material and Methods}

\subsection{Biological Objects}

The object of the research was a strain of inosine producer, spore-forming aerobic Gram-positive chemoheterotrophic bacterium B. subtilis B-3157, polyauxotrophic for histidine, tyrosine, adenine, and uracil (demand, $10 \mathrm{mg} / \mathrm{l}$ ), obtained from Institute of Genetics and Selection of Industrial Microorganisms (Russia). The initial strain was adapted to deuterium by plating individual colonies onto $2 \%(\mathrm{w} / \mathrm{v})$ agarose with stepwise increasing gradient of ${ }^{2} \mathrm{H}_{2} \mathrm{O}$ concentration and subsequent selection of individual cell colonies stable to the action of ${ }^{2} \mathrm{H}_{2} \mathrm{O}$.

\subsection{Water Samples}

The research by the IR-spectrometry (DNES-method) was carried out with samples of water taken from various water springs of Bulgaria:

1 - Mineral water (Rupite, Bulgaria);

2 - Seawater (Varna resort, Bulgaria);

3 - Mountain water (Teteven, Bulgaria);

5 - Deionized water (the control).

6 - Water with varying deuterium content (HDO).

As model systems were used cactus juice of Echinopsis pachanoi.

\subsection{Chemicals}

For preparation of growth media was ${ }^{2} \mathrm{H}_{2} \mathrm{O}\left(99.9\right.$ atom $\left.\%{ }^{2} \mathrm{H}\right),{ }^{2} \mathrm{HCl}\left(95.5\right.$ atom $\left.\%{ }^{2} \mathrm{H}\right)$, and $\left[{ }^{2} \mathrm{H}\right]$ methanol $(97.5$ atom $\%{ }^{2} \mathrm{H}$ ), purchased from JSC "Izotop" (St. Petersburg, Russian Federation). 5-dimethylamino(naphthalene)1-sulfonyl (dansyl chloride) of analytical reagent grade was from Sigma-Aldrich Corporation (St. Louis, USA). Deionized water was provided by the Milli-Q integral water purification system ("Millipore", USA). Inorganic salts and D- and L-glucose ("Reanal", Hungary) were initially crystallized in 99.9 atom\% ${ }^{2} \mathrm{H}_{2} \mathrm{O}$. ${ }^{2} \mathrm{H}_{2} \mathrm{O}$ was distilled over $\mathrm{KMnO}_{4}$ with subsequent control of the isotope purity by NMR spectroscopy on a Brucker WM-250 ("Brucker Corp.", USA) with a working frequency of $70 \mathrm{MHz}$ (internal standard - $\mathrm{Me}_{4} \mathrm{Si}$ ).

\subsection{Biosynthesis of ${ }^{2} \mathrm{H}$-Inosine}

$\left[{ }^{2} \mathrm{H}\right]$ inosine was produced with an output $3.9 \mathrm{~g} / \mathrm{l}$ in heavy water $(\mathrm{HW})$ medium $\left(89-90\right.$ atom\% $\left.{ }^{2} \mathrm{H}\right)$ with $2 \%(\mathrm{w} / \mathrm{v})$ hydrolysate of deuterated biomass of methanol-assimilating strain of the facultative Gram-negative methylotrophic bacterium Brevibacterium methylicum as a source of ${ }^{2} \mathrm{H}$-labeled growth substrates. The strain was obtained by multistage adaptation on a solid $2 \%(\mathrm{w} / \mathrm{w})$ agarose M9 minimal medium containing $3 \mathrm{~g} / \mathrm{l}$ $\mathrm{KH}_{2} \mathrm{PO}_{4}, 6 \mathrm{~g} / 1 \mathrm{Na}_{2} \mathrm{HPO}_{4}, 0.5 \mathrm{~g} / 1 \mathrm{NaCl}$, and $1 \mathrm{~g} / 1 \mathrm{NH}_{4} \mathrm{Cl}$ with $\left.2 \%(\mathrm{v} / \mathrm{v}){ }^{2} \mathrm{H}\right]$ methanol and a stepwise increasing ${ }^{2} \mathrm{H}_{2} \mathrm{O}$ concentration gradient $\left(0,24.5,73.5\right.$, and $98 \%$ (v/v) ${ }^{2} \mathrm{H}_{2} \mathrm{O}$ ). A raw methylotrophic biomass (yield, $200 \mathrm{~g} / \mathrm{l}$ ) was suspended in $100 \mathrm{ml} 0.5 \mathrm{~N}^{2} \mathrm{HCl}$ (in ${ }^{2} \mathrm{H}_{2} \mathrm{O}$ ) and autoclaved for $30-40 \mathrm{~min}$ at $0.8 \mathrm{~atm}$. The resulting suspension was neutralized with $0.2 \mathrm{~N} \mathrm{KOH}$ (in ${ }^{2} \mathrm{H}_{2} \mathrm{O}$ ) to $\mathrm{pH}=7.0$, and used as a source of growth substrates when cultivating the inosine producer strain. For this purpose, an inoculum $(5-6 \%(\mathrm{w} / \mathrm{w}))$ was added to the HW 
medium with ${ }^{2} \mathrm{H}_{2} \mathrm{O}$ containing $12 \%$ (w/w) glucose, $2 \%$ (w/w) hydrolysate of deuterated biomass B. methylicum, $2 \%(\mathrm{w} / \mathrm{w}) \mathrm{NH}_{4} \mathrm{NO}_{3}, 1 \%$ (w/w) $\mathrm{MgSO}_{4} 7 \mathrm{H}_{2} \mathrm{O}, 2 \%$ (w/w) $\mathrm{CaCO}_{3}, 0.01 \%$ (w/w) adenine, and $0.01 \%$ (w/w) uracil. A protonated medium with $2 \%(\mathrm{w} / \mathrm{w})$ yeast protein-vitamin concentrate $(\mathrm{PVC})$ was used as a control.

\subsection{Growth Conditions}

Bacteria were grown in $500 \mathrm{ml}$ Erlenmeyer flasks (containing $100 \mathrm{ml}$ of the growth medium) for 3-4 days at $32^{\circ} \mathrm{C}$ under intensive aeration in a Biorad orbital shaker ("Biorad Labs", Hungary). The bacterial growth was controlled on the ability to form individual colonies on the surface of solid (2\% (w/w) agarose) media, as well as the optical density of the cell suspension measured on a Beckman DU-6 spectrophotometer ("Beckman Coulter", USA) at $\lambda=540 \mathrm{~nm}$ in a quartz cuvette with an optical pathway length $10 \mathrm{~mm}$.

\subsection{Analytical Determination of $\left[{ }^{2}\right.$ H]Inosine}

Inosine was analytically determined in culture liquid samples with a volume of $10 \mu 1$ on Silufol UV-254 chromatographic plates $(150 \times 150 \mathrm{~mm})$ ("Kavalier", Czech Republic) using a standard set of ribonucleosides "Beckman-Spinco" (USA) in the solvent system: $n$-butanol-acetic acid-water $(2: 1: 1, \%(\mathrm{v} / \mathrm{v}))$. Spots were eluted with $0.1 \mathrm{~N} \mathrm{HCl}$. The UV absorption of eluates was recorded on a Beckman DU-6 spectrophotometer ("Beckman Coulter", USA) using a standard calibration plot. The level of bioconversion of the carbon substrate was assessed using glucose oxidase (EC 1.1.3.4).

\subsection{Hydrolysis of Intracellular Polycarbohydrates}

Dry deuterated biomass $(50 \mathrm{mg}$ ) was placed into a $250 \mathrm{ml}$ round bottomed flask, supplemented with $50 \mathrm{ml}$ distilled ${ }^{2} \mathrm{H}_{2} \mathrm{O}$ and $1.6 \mathrm{ml} \mathrm{25 \%}(\mathrm{v} / \mathrm{v}) \mathrm{H}_{2} \mathrm{SO}_{4}\left(\right.$ in $\left.{ }^{2} \mathrm{H}_{2} \mathrm{O}\right)$, and boiled in a reflux water evaporator for $\sim 90 \mathrm{~min}$. After cooling, the reaction mixture was suspended in one volume of hot distilled ${ }^{2} \mathrm{H}_{2} \mathrm{O}$ and neutralized with $1 \mathrm{~N}$ $\mathrm{Ba}(\mathrm{OH})_{2}$ (in ${ }^{2} \mathrm{H}_{2} \mathrm{O}$ ) to $\mathrm{pH}=7.0 . \mathrm{BaSO}_{4}$ was separated by centrifugation on a $\mathrm{T}-24$ centrifuge ("Heraues Separatech", Germany) (1500 g, $5 \mathrm{~min}$ ); the supernatant was decanted and evaporated at $10 \mathrm{~mm} \mathrm{Hg}$.

\subsection{Amino Acid Analysis}

The amino acids of the hydrolyzed biomass were analyzed on a Biotronic LC-5001 $(230 \times 3.2)$ column ("Eppendorf-Nethleler-Hinz", Germany) with a UR-30 ("Beckman-Spinco", USA) sulfonated styrene (7.25\% crosslinked) resin as a stationary phase; the granule diameter was $25 \mu \mathrm{m} ; 0.2 \mathrm{~N}$ sodium-citrate buffer $(\mathrm{pH}=2.5)$ was used as an eluent; the working pressure - 50-60 atm; the eluent input rate $-18.5 \mathrm{ml} / \mathrm{h}$; the ninhydrin input rate $-9.25 \mathrm{ml} / \mathrm{h}$; detection at $\lambda=570$ and $\lambda=440 \mathrm{~nm}$ (for proline).

\subsection{Analysis of Carbohydrates}

Carbohydrates were analyzed on a Knauer Smartline chromatograph ("Knauer", Germany) equipped with a Gilson pump ("Gilson Inc.", Germany) and Waters K 401 refractometer ("Water Associates", Germany) using Ultrasorb CN C18 as a stationary phase: the column size $-250 \times 10 \mathrm{~mm}$; the granule diameter $-10 \mu \mathrm{m}$; the mobile phase - acetonitrile-water $(75: 25, \%(\mathrm{v} / \mathrm{v})$; the input rate $-0.6 \mathrm{ml} / \mathrm{min}$.

\subsection{FAB Mass Spectrometry}

FAB mass spectra were recorded on a VG-70 SEQ chromatograph ("Fisons VG Analytical", USA) equipped with a cesium source on a glycerol matrix with accelerating voltage $5 \mathrm{kV}$ and ion current $0.6-0.8 \mathrm{~mA}$.

\subsection{EI Mass Spectrometry}

EI mass spectra were recorded with an MB-80A device (Hitachi, Japan) with double focusing (the energy of ionizing electrons $-70 \mathrm{eV}$; the accelerating voltage $-8 \mathrm{kV}$; the cathode temperature $\left.-180-200^{\circ} \mathrm{C}\right)$ after amino acid modification into methyl esters of N-5-dimethylamino(naphthalene)-1-sulfonyl (dansyl) amino acid derivatives according to an earlier elaborated protocol (Mosin \& Ignatov, 2013).

\subsection{IR Spectroscopy}

Samples of water for the research by the IR-spectroscopy method were taken from various sources of Bulgaria: 1 - hot mineral water $\left(75^{\circ} \mathrm{C}\right.$ ) from Rupite village (Bulgaria); 2 - sea water (Varna, Bulgaria); 3 - cactus juice of Echinopsis pachanoi. IR-spectra were registered by Dr. Kristina Chakarova (Bulgarian Academy of Sciences, Sofia, Bulgaria) on Fourier-IR spectrometer Brucker Vertex ("Brucker", Germany) (a spectral range: average IR $-370-7800 \mathrm{~cm}^{-1}$; visible $-2500-8000 \mathrm{~cm}^{-1}$; the permission $-0.5 \mathrm{~cm}^{-1}$; accuracy of wave number $-0.1 \mathrm{~cm}^{-1}$ on $\left.2000 \mathrm{~cm}^{-1}\right)$. 


\section{Results and Discussion}

\subsection{Isotopic Effects of Deuterium in Chemoheterotrophic Bacterium B. Subtilis}

We have investigated isotopic effects of deuterium in prokaryotic cells of various taxonomic groups of microorganisms including chemoheterotrophic bacteria, which are believed to be at early stages of evolution, because glycolysis is accepted to be an ancient pathway of carbon assimilation. As a model for our experiments was used an inosine producer mutant strain of a Gram-positive aerobic spore-forming chemoheterotrophic bacterium B. subtilis VKPM B-3157 (Mosin et al., 1999) polyauxotrophic for histidine, tyrosine, adenine, and uracil (preliminary adapted to deuterium by selection of individual colonies on solid $2 \%$ (w/v) agarose growth media with 99.9 atom $\%{ }^{2} \mathrm{H}_{2} \mathrm{O}$ ).

Most aerobic chemoheterotrophic bacteria are able to use as a source of growth substrates a variety of simple organic compounds (sugars, amino acids, organic acids). Some representatives of chemoheterotrophic bacteria can ferment carbohydrates. Some species do not require organic growth factors, while others require amino acids, growth factors, or vitamin $\mathrm{B}_{2}, \mathrm{~B}_{6}, \mathrm{~B}_{12}$ or both. Most aerobic spore-forming bacteria are mesophylls with a temperature optimum between $+30{ }^{0} \mathrm{C}$ and $+45{ }^{\circ} \mathrm{C}$, represented mainly by rod-shaped (Fig. 1).
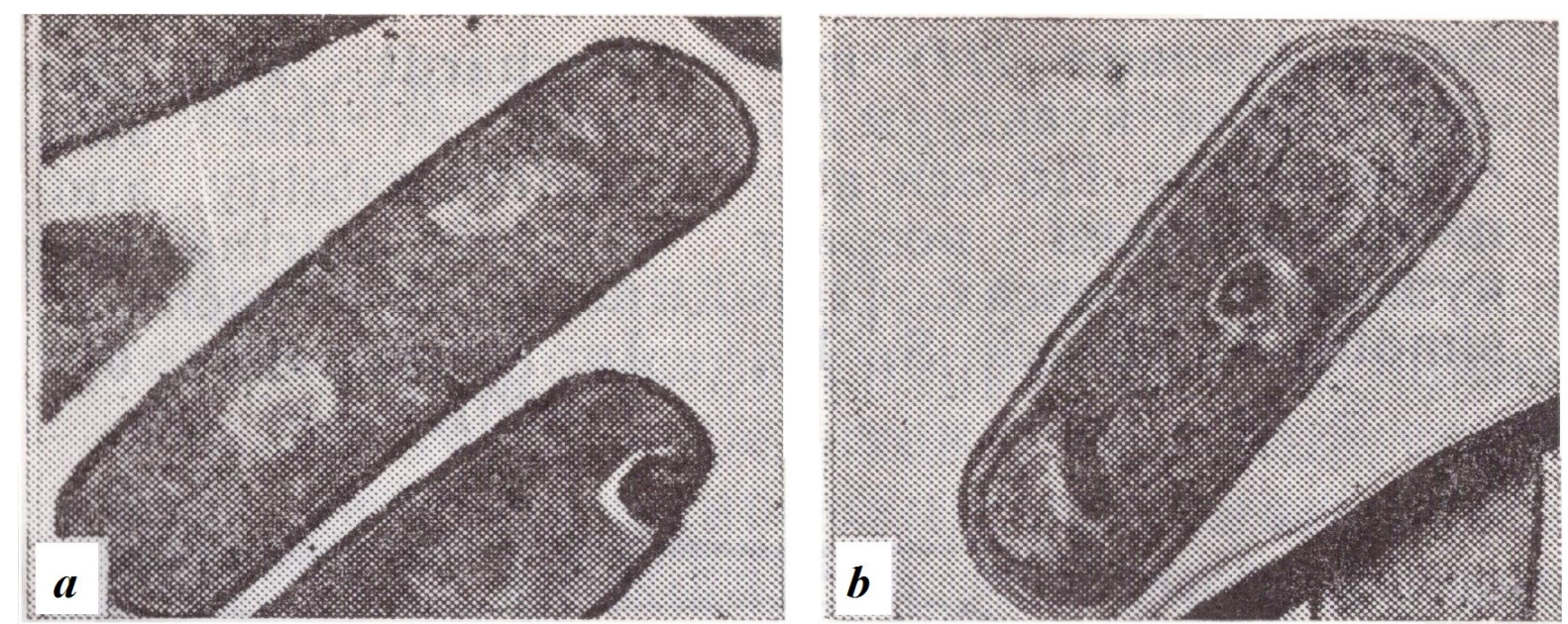

Figure 1: Electron micrographs of ultrathin sections of B. subtilis: a) - vegetative cells in the exponential growth phase; b) -combining of nucleoids with the formation of rod-shaped structures (adapted from Ryter A., 1965)

Because of impaired metabolic pathways involved in the regulation of the biosynthesis of purine ribonucleosides (adenine, uracil, and inosine), this strain of a Gram-positive aerobic spore-forming chemoheterotrophic bacterium $B$. subtilis VKPM B-3157 under standard growth conditions (PVC medium, late exponential growth, $+32^{\circ} \mathrm{C}$ ) synthesizes 17-20 gram of inosine per 1 liter of cultural medium (Mosin et al., 2013). The maximal inosine yield for this strain was reached on a protonated growth medium with $12 \%(\mathrm{w} / \mathrm{v})$ glucose as a source of carbon and energy and 2\% (w/v) yeast PVC as a source of growth factors and amine nitrogen. In our experiments it was necessary to replace the protonated growth substrates with their deuterated analogs, as well as to use ${ }^{2} \mathrm{H}_{2} \mathrm{O}$ of high isotopic purity. For this purpose, we used autoclaved biomass of the Gram-negative facultative methylotrophic bacterium Brevibacterium methylicum B-5662 strain adapted to deuterium capable to assimilate methanol via the ribulose-5-monophosphate (RuMP) pathway of carbon assimilation. Owing to a 50$60 \%$ rate of methanol bioconversion (conversion efficiency, 15.5-17.3 gram of dry biomass per 1 gram of assimilated substrate) and stable growth in a deuterated M9 minimal medium with $98 \%(\mathrm{v} / \mathrm{v}){ }^{2} \mathrm{H}_{2} \mathrm{O}$ and $2 \%(\mathrm{v} / \mathrm{v})$ $\left[{ }^{2} \mathrm{H}\right]$ methanol, this strain is the most convenient source for producing deuterated biomass; moreover, the cost of bioconversion is mainly determined by the cost of ${ }^{2} \mathrm{H}_{2} \mathrm{O}$ and $\left[{ }^{2} \mathrm{H}\right]$ methanol. 
Table 1. Amino acid composition of hydrolyzed biomass of the facultative methylotrophic bacterium $B$. methylicum obtained on a maximally deuterated M9 medium with $98 \%(\mathrm{v} / \mathrm{v}){ }^{2} \mathrm{H}_{2} \mathrm{O}$ and $2 \%(\mathrm{v} / \mathrm{v})\left[{ }^{2} \mathrm{H}\right]$ methanol and levels of deuterium enrichment*

\begin{tabular}{|c|c|c|c|c|}
\hline Amino acid & \multicolumn{2}{|c|}{ Yield, \% (w/w) dry weight per 1 gram of } \\
biomass & $\begin{array}{c}\text { Number of } \\
\text { deuterium } \\
\text { atoms incorporated } \\
\text { into the carbon } \\
\text { backbone of a } \\
\text { molecule** }\end{array}$ & $\begin{array}{c}\text { Level of deuterium } \\
\text { enrichment of } \\
\text { molecules, \% of } \\
\text { the total number of } \\
\text { hydrogen } \\
\text { atoms*** }\end{array}$ \\
\hline Glycine & 8.03 & $\begin{array}{c}\text { Sample from } \\
\text { deuterated M9 } \\
\text { medium }\end{array}$ & 2 & 90.0 \\
\hline Alanine & 12.95 & 9.69 & 4 & 97.5 \\
\hline Valine & 3.54 & 13.98 & 4 & 50.0 \\
\hline Leucine & 8.62 & 3.74 & 5 & 49.0 \\
\hline Isoleucine & 4.14 & 7.33 & 5 & 49.0 \\
\hline Phenylalanine & 3.88 & 3.64 & 8 & 95.0 \\
\hline Tyrosine & 1.56 & 3.94 & 7 & 86.8 \\
\hline Serine & 4.18 & 1.83 & 3 & - \\
\hline Threonine & 4.81 & 4.90 & - & - \\
\hline Methionine & 4.94 & 5.51 & - & 66.6 \\
\hline Asparagine & 7.88 & 2.25 & 2 & 70.0 \\
\hline Glutamic acid & 11.68 & 9.59 & 4 & 58.9 \\
\hline Lysine & 4.34 & 10.38 & 5 & - \\
\hline Arginine & 4.63 & 3.98 & - & - \\
\hline Histidine & 3.43 & 5.28 & - & \\
\hline
\end{tabular}

Notes:

* The data were obtained for methyl esters of N-5-dimethylamino(naphthalene)-1-sulfonyl (dansyl) chloride amino acid derivatives.

** When calculating the level of deuterium enrichment, the protons(deuterons) at the carboxyl $\mathrm{COOH}-$ and amino $\mathrm{NH}_{2^{-}}$groups of amino acid molecules were not taken into account because of the dissociation in $\mathrm{H}_{2} \mathrm{O} /{ }^{2} \mathrm{H}_{2} \mathrm{O}$.

*** A dash denotes the absence of data.

The strategy for the biosynthesis of $\left[{ }^{2} \mathrm{H}\right]$ inosine using biomass of B. methylicum as growth substrates was developed taking into account the ability of methylotrophic bacteria to synthesize large amounts of proteins (output, 50\% (w/w) of dry weight), 15-17\% (w/w) of polysaccharides, 10-12\% (w/w) of lipids (mainly, phospholipids), and 18\% (w/w) of ash (Mosin et al., 1998). To provide high outputs of these compounds and minimize the isotopic exchange $\left({ }^{1} \mathrm{H}-{ }^{2} \mathrm{H}\right)$ in amino acid residues of protein molecules, the biomass was hydrolyzed by autoclaving in $0.5 \mathrm{M}{ }^{2} \mathrm{HCl}$ (in ${ }^{2} \mathrm{H}_{2} \mathrm{O}$ ). Since the B. subtilis inosine-producing strain is a polyauxotroph requiring tyrosine and histidine for its growth, we studied the qualitative and quantitative compositions of the amino acids in the hydrolyzed methylotrophic biomass produced in the maximally deuterated medium M9 (98\% (v/v) ${ }^{2} \mathrm{H}_{2} \mathrm{O}$ and $2 \%$ (v/v) $\left[{ }^{2} \mathrm{H}\right]$ methanol), and the enrichment levels (Table 1). The methylotrophic hydrolysate contains 15 identified amino acids (except for proline, detectable at $\lambda=440 \mathrm{~nm}$ ) with tyrosine and histidine contents per 1 gram of dry methylotrophic hydrolysate $1.82 \%$ and $3.72 \%$ (w/w), respectively, thereby surrisfying the auxotrophic requirements of the inosine producer strain of $B$. subtilis for these amino acids. The contents of other amino acids in the hydrolysate are also comparable with the needs of the strain in sources of carbon and amine nitrogen (Table 1). The indicator determining the high efficiency of deuterium incorporation into the synthesized product is high degrees of deuterium enrichment of amino acid molecules, which vary from 49 atom $\%{ }^{2} \mathrm{H}$ for leucine/isoleucine to 97.5 atom $\%{ }^{2} \mathrm{H}$ for alanine (Table 1). This allowed use the hydrolysate of deuterated $B$. methylicum biomass as a source of growth substrates for cultivating the B. subtilis inosine-producing strain.

The growth and biosynthetic characteristics of inosine-producing strain B. subtilis were studied on a protonated yeast PVC medium with $\mathrm{H}_{2} \mathrm{O}$ and $2 \%$ (w/w) yeast PVC and on an $\mathrm{HW}$ medium with $89 \%$ (v/v) ${ }^{2} \mathrm{H}_{2} \mathrm{O}$ and $2 \%$ (w/w) hydrolysate of deuterated biomass of B. methylicum (Figure 1). The experiments demonstrated a certain correlation between the changes of growth dynamics of B. subtilis (Fig. 2, curves $1, l^{\prime}$ ), output of inosine (Fig. 2 , curves 2, 2'), and glucose assimilation (Fig. 3, curves 3, 3'). The maximal output of inosine (17 g/l) was observed on protonated PVC medium at a glucose assimilation rate $10 \mathrm{~g} / \mathrm{l}$ (Fig. 2, curve 2). The output of inosine in the HW medium decreased 4.4-fold, reaching 3.9 g/l (Fig. 2, curve 2'), and the level of glucose assimilation, 4-fold, 
as suggested by the remaining $40 \mathrm{~g} / \mathrm{l}$ unassimilated glucose in cultural medium (Fig. 2, curve 3'). The experimental data demonstrate that glucose is less efficiently assimilated during the growth in the HW medium as compared to the control conditions. This result demanded the examination of the content of glucose and other intracellular carbohydrates in the biomass of the inosine-producer strain of B. subtilis, which was performed by reverse phase HPLC on an Ultrasorb CN column $(10 \mu \mathrm{m}, 10 \times 250 \mathrm{~mm})$ with a mixture of acetonitrile-water $(75$ : 25, \% (v/v)) as a mobile phase (Table 2). The fraction of intracellular carbohydrates in Table 2 (numbered according to the sequence of their elution from the column) comprises monosaccharides (glucose, fructose, rhamnose, and arabinose), disaccharides (maltose and sucrose), and four unidentified carbohydrates with retention times of $3.08(15.63 \%(\mathrm{w} / \mathrm{w})), 4.26(7.46 \%(\mathrm{w} / \mathrm{w})), 7.23(11.72 \%(\mathrm{w} / \mathrm{w}))$, and $9.14(7.95 \%(\mathrm{w} / \mathrm{w}) \mathrm{min}$ (not shown). As was expected, the output of glucose in the deuterated hydrolysate was $21.4 \%(\mathrm{w} / \mathrm{w})$ of dry weight, that is, higher than the outputs of fructose $(6.82 \%(\mathrm{w} / \mathrm{w}))$, rhamnose $(3.47 \%(\mathrm{w} / \mathrm{w}))$, arabinose $(3.69 \%$ $(\mathrm{w} / \mathrm{w}))$, and maltose $(11.62 \%(\mathrm{w} / \mathrm{w}))$ (Table 2$)$. Their outputs in microbial biomass did not differ considerably related to the control in $\mathrm{H}_{2} \mathrm{O}$ except for sucrose, which is undetectable in the deuterated sample. The levels of deuterium enrichment in carbohydrates varied from 90.7 atom $\%{ }^{2} \mathrm{H}$ for arabinose to 80.6 atom $\%{ }^{2} \mathrm{H}$ for glucose.

Table 2: Qualitative and quantitative compositions of intracellular carbohydrates isolated from B. subtilis after growing on HW-medium and levels of the deuterium enrichment*

\begin{tabular}{|c|c|c|c|}
\hline \multirow{2}{*}{ Carbohydrate } & \multicolumn{2}{|c|}{ Content in biomass, \% (w/w) of 1 g of dry biomass } & $\begin{array}{c}\text { Level of deuterium } \\
\text { enrichment of } \\
\text { molecules, \%** }\end{array}$ \\
\cline { 2 - 4 } & Protonated sample (control) & $\begin{array}{c}\text { Sample from the HW } \\
\text { medium }\end{array}$ & $80.6 \pm 1.86$ \\
\hline Glucose & 20.01 & 21.40 & $85.5 \pm 1.92$ \\
\hline Fructose & 6.12 & 6.82 & $90.3 \pm 2.12$ \\
\hline Rhamnose & 2.91 & 3.47 & $90.7 \pm 3.10$ \\
\hline Arabinose & 3.26 & 3.69 & - \\
\hline Maltose & 15.30 & 11.62 & - \\
\hline Sucrose & 8.62 & ND $^{* *}$ & - \\
\hline
\end{tabular}

Notes:

* The data were obtained by IR-spectroscopy.

$* *$ ND - not detected.

*** A dash denotes the absence of data.

Assimilation of glucose, g/l Accumulation of inosine, $\mathrm{g} / \mathrm{l}$

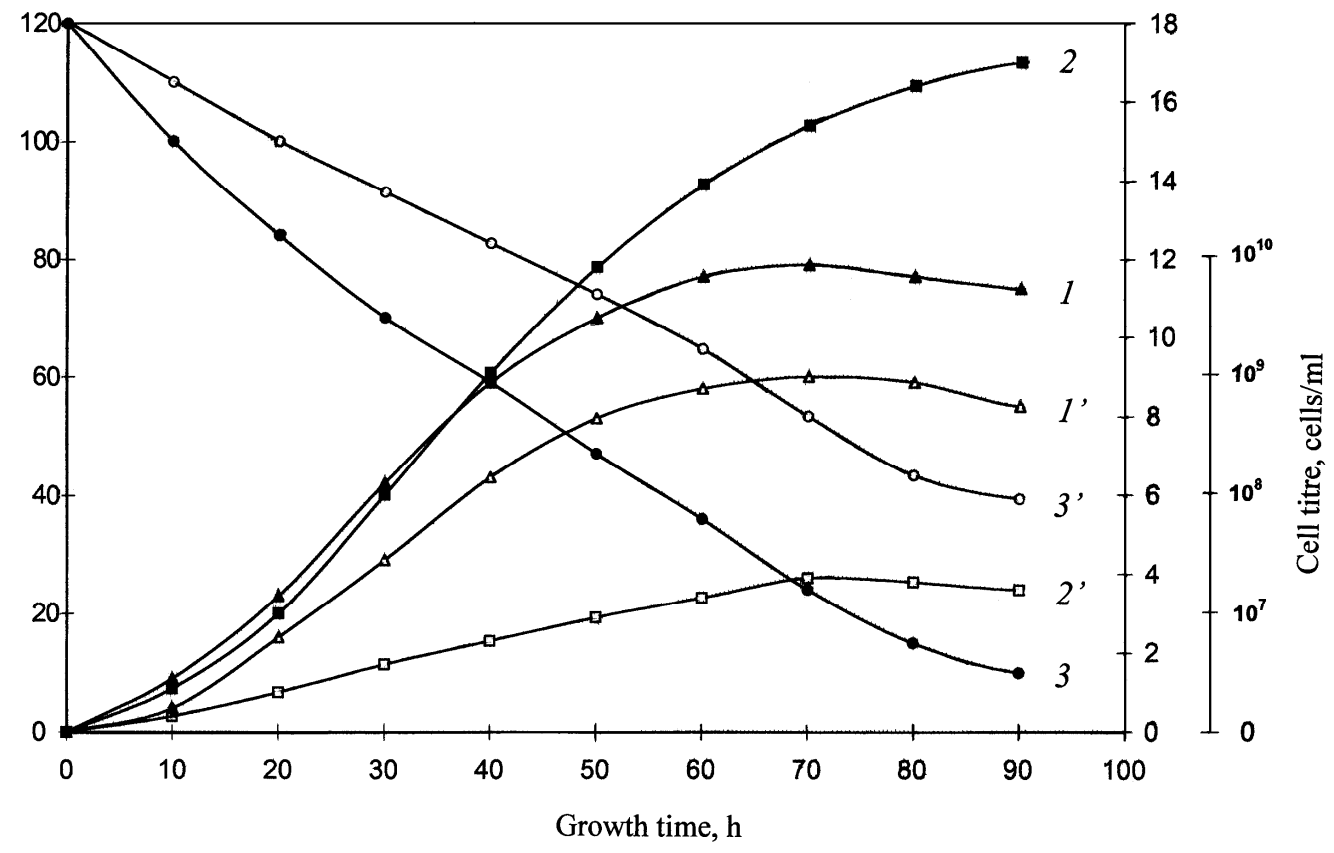

Figure 2. Growth dynamics of $B$. subtilis $\left(1,1^{\prime}\right)$ (cells/ml), $\left(2,2^{\prime}\right)$ inosine accumulation in cultural medium (g/l), and $(3,3)$ glucose assimilation (g/l) under different experimental conditions: $(1-3)$ - a protonated yeast PVC medium and $\left(l^{\prime}-3^{\prime}\right)-\mathrm{HW}$ medium with $2 \%(\mathrm{w} / \mathrm{w})$ hydrolysate of deuterated biomass of $B$. methylicum. 
The using of a combination of physical-chemical methods for isolating $\left[{ }^{2} \mathrm{H}\right]$ inosine from the cultural medium of the inosine producer strain was determined by the need for preparing inosine of a high chromatographic purity (no less than 95\%). Since cultural medium contains inorganic salts, proteins, and polysaccharides, along with inosine, as well as accompanying secondary metabolites of nucleic nature (adenosine and guanosine) and unreacted substrates (glucose and amino acids), the cultural medium was fractionated in a stepwise manner for isolating $\left[{ }^{2} \mathrm{H}\right]$ inosine. The fractionation consisted in low-temperature precipitation of high molecular weight impurities with organic solvents (acetone and methanol), adsorption/desorption on the surface of activated carbon, extraction of the end product, crystallization, and ion exchange chromatography. The proteins and polysaccharides were removed by low temperature precipitation with acetone at $+4^{\circ} \mathrm{C}$ with subsequent adsorption of total ribonucleosides on activated carbon in the cold. The desorbed ribonucleosides were extracted from the reacted solid phase by eluting with $\mathrm{EtOH}-\mathrm{NH}_{3}$-solution at $\mathrm{t}=+60{ }^{0} \mathrm{C}$; inosine - by extracting with 0.3 $\mathrm{M}$ ammonium-formate buffer $(\mathrm{pH}=8.9)$ with subsequent crystallization in $80 \%(\mathrm{v} / \mathrm{v})$ of ethanol. The final purification consisted in column ion exchange chromatography on AG50WX 4 cation exchange resin equilibrated with $0.3 \mathrm{M}$ ammonium-formate buffer containing $0.045 \mathrm{M} \mathrm{NH}_{4} \mathrm{Cl}$ with collection of fractions at $R_{f}$ $=0.5$. Figure 3 (curves 1-3) shows UV-absorption spectra of inosine isolated from the cultural medium. The presence of major absorption band I, corresponding to natural inosine $\left(\lambda_{\max }=249 \mathrm{~nm}, \varepsilon_{249}=7100 \mathrm{M}^{-1} \mathrm{~cm}^{-1}\right)$, as well as the absence of secondary metabolites II and III in the obtained sample (Fig. 2, curve 3), demonstrates its uniformity and the efficiency of the isolation method.

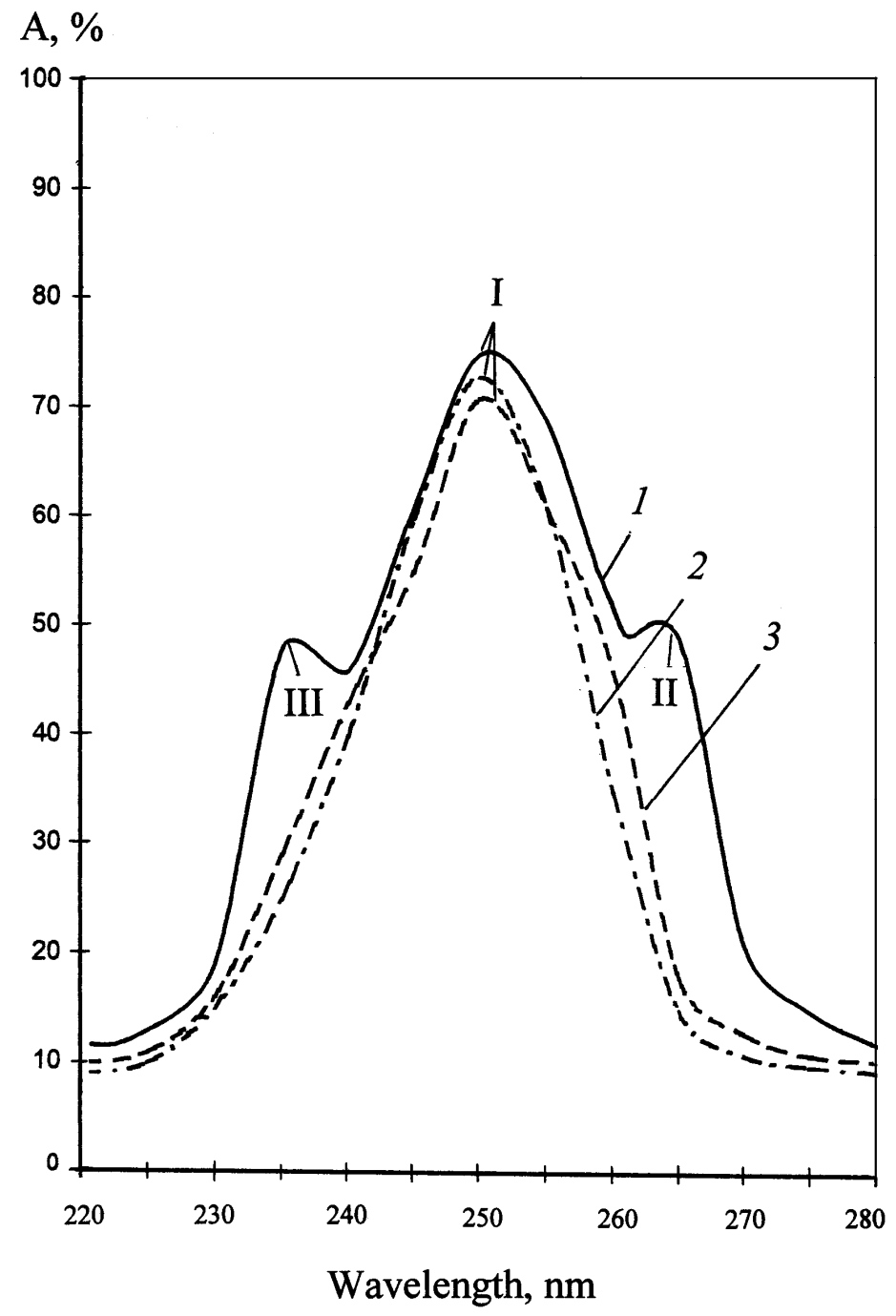

Figure 3: UV-absorption spectra of inosine $(0.1 \mathrm{~N} \mathrm{HCl})$ : $(1)-$ initial LC after the growth of $B$. subtilis on HW medium; (2) - natural inosine, and (3) - inosine extracted from the LC. Natural inosine (2) was used as a control: (I) - inosine, (II, III) - secondary metabolites. 
The level of deuterium enrichment of the $\left[{ }^{2} \mathrm{H}\right]$ inosine molecule was determined by FAB mass spectrometry, the high sensitivity of which allows to detect $10^{-8}$ to $10^{-10}$ moles of a substance in a sample. The formation of a molecular ion peak for inosine in FAB mass spectrometry was accompanied by the migration of $\mathrm{H}^{+}$. Biosynthetically ${ }^{2} \mathrm{H}$-labeled inosine, which FAB mass-spectrum represented in Figure $4 b$ regarding the control (natural protonated inosine, Figure $4 a$ ), represented a mixture of isotope-substituted molecules with different numbers of hydrogen atoms replaced by deuterium. Correspondingly, the molecular ion peak of inosine [M + $\mathrm{H}]^{+}$, was polymorphically splintered into individual clusters with admixtures of molecules with statistical set of mass numbers $\mathrm{m} / \mathrm{z}$ and different contributions to the total level of deuterium enrichment of the inosine molecule. Therefore, the molecular ion peak of inosine was calculated according to the most intensive molecular ion peak (the peak with the largest contribution to the level of deuterium enrichment) recorded by a mass spectrometer under the same experimental conditions. These conditions are satisfied the most intensive molecular ion peak [M $+\mathrm{H}]^{+}$at $\mathrm{m} / \mathrm{z}=274$ with $38 \%$ (instead of $[\mathrm{M}+\mathrm{H}]^{+}$at $\mathrm{m} / \mathrm{z}=269$ with $42 \%$ under the control conditions; Figure $4 a$ ). That result corresponds to five deuterium atoms incorporated into the inosine molecule (Figure $4 \mathrm{~b}$ ). The molecular ion peak of inosine also contained less intensive peaks with admixtures of molecules containing four $(\mathrm{m} / \mathrm{z}=273,20 \%)$, five $(\mathrm{m} / \mathrm{z}=274,38 \%)$, six $(\mathrm{m} / \mathrm{z}=275,28 \%)$, and seven $(\mathrm{m} / \mathrm{z}=276,14 \%)$ deuterium atoms (Table 3).

Table 3: Values of peaks $[\mathrm{M}+\mathrm{H}]^{+}$in the FAB mass spectra and levels of deuterium enrichment of inosine isolated from $\mathrm{HW}$-medium

\begin{tabular}{|c|c|c|c|}
\hline Value of peak $[\mathrm{M}+\mathrm{H}]^{+}$ & $\begin{array}{c}\text { Contribution to the level } \\
\text { of deuterium } \\
\text { enrichment, mol.\% }\end{array}$ & $\begin{array}{c}\text { The number of } \\
\text { deuterium atoms }\end{array}$ & $\begin{array}{c}\text { Level of deuterium enrichment } \\
\text { of molecules, \% of the total } \\
\text { number of hydrogen atoms* }\end{array}$ \\
\hline 273 & 20 & 4 & $20.0 \pm 0.60$ \\
\hline 274 & 38 & 5 & $62.5 \pm 1.80$ \\
\hline 275 & 28 & 6 & $72.5 \pm 1.96$ \\
\hline 276 & 14 & 7 & $87.5 \pm 2.98$ \\
\hline
\end{tabular}

\section{*Notes:}

At calculation of the level of deuterium enrichment, the protons(deuterons) at the hydroxyl $\left(\mathrm{OH}^{-}\right)$and imidazole protons at $\mathrm{NH}^{+}$heteroatoms were not taken into account because of keto-enol tautomerism in $\mathrm{H}_{2} \mathrm{O} /{ }^{2} \mathrm{H}_{2} \mathrm{O}$.

Taking into account the contribution of the molecular ion peaks $[\mathrm{M}]^{+}$, the total level of deuterium enrichment (TLDE) of the inosine molecule calculated using the below equation was $65.5 \%$ of the total number of hydrogen atoms in the carbon backbone of the molecule:

$$
T L D E=\frac{[M]_{r 1}^{+} \cdot C_{2}+[M]_{r 2}^{+} \cdot C_{2}+\ldots+[M]_{r n}^{+} \cdot C_{n}}{\sum C_{n}}
$$

where $[M]_{r}^{+}$- the values of the molecular ion peaks of inosine.

$C_{n}$ - the contribution of the molecular ion peaks to TLDE (mol \%). 

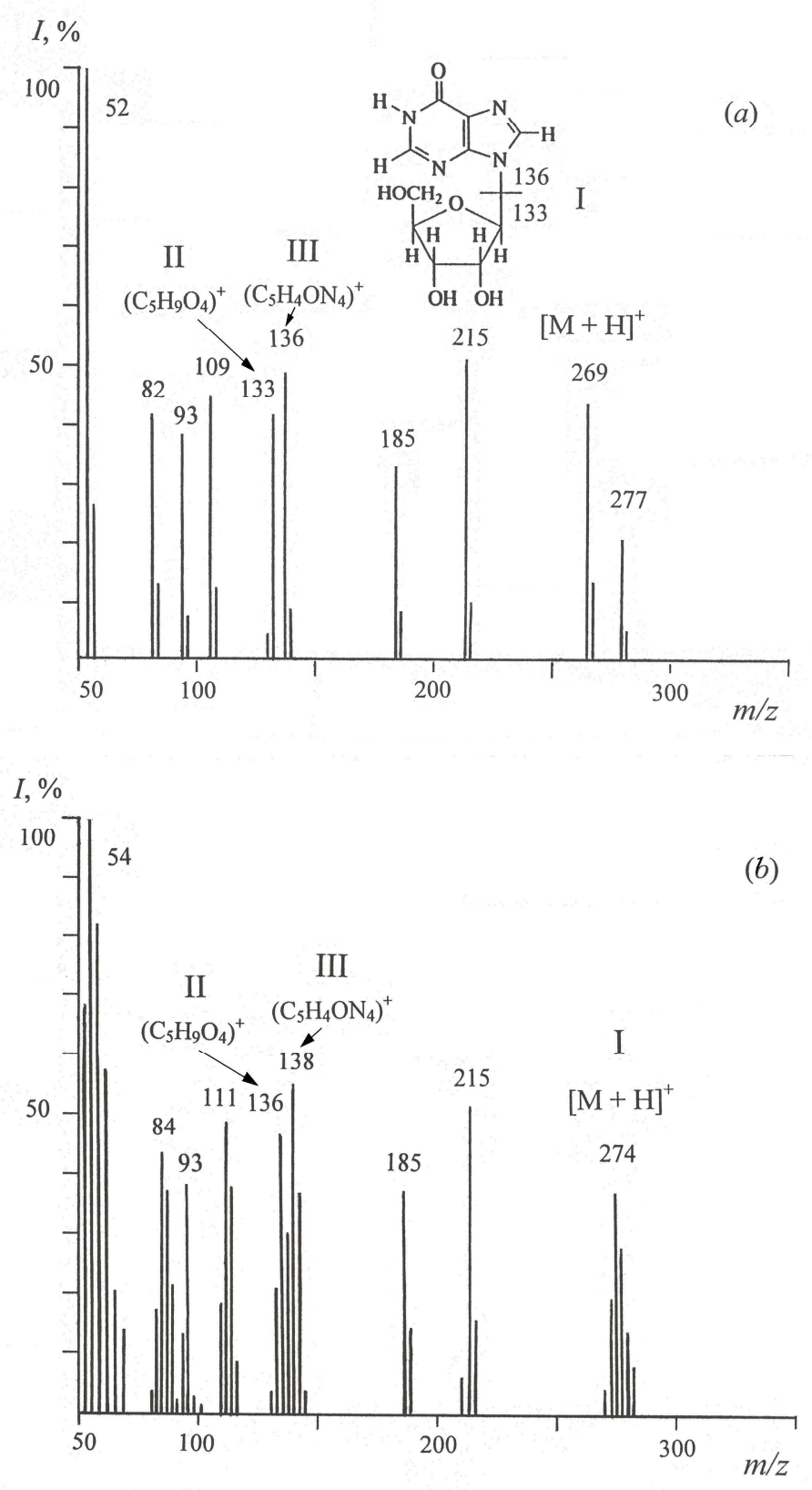

Figure 4: FAB mass spectra of inosine (glycerol as a matrix) under different experimental conditions: $(a)$ natural inosine; $(b)-\left[{ }^{2} \mathrm{H}\right]$ inosine isolated from HW medium (scanning interval at $\mathrm{m} / \mathrm{z}$ 50-350; major peaks with a relative intensity of $100 \%$ at $\mathrm{m} / \mathrm{z} 52$ and $\mathrm{m} / \mathrm{z}$ 54; ionization conditions: cesium source; accelerating voltage, 5 $\mathrm{kV}$; ion current, $0.6-0.8 \mathrm{~mA}$; resolution, 7500 arbitrary units): $I$ - relative intensity of peaks (\%); (I) - inosine; (II) - ribose fragment; (III) - hypoxanthine fragment.

The fragmentation of the inosine molecule by the FAB-method, shown in Figure 5, gives more precise information on the deuterium distribution in the molecule. The FAB fragmentation pathways of the inosine molecule (I) lead to formation of ribose $\left(\mathrm{C}_{5} \mathrm{H}_{9} \mathrm{O}_{4}\right)^{+}$fragment (II) at $\mathrm{m} / \mathrm{z}=133$ and hypoxanthine $\left(\mathrm{C}_{5} \mathrm{H}_{4} \mathrm{ON}_{4}\right)^{+}$ fragment (III) at $\mathrm{m} / \mathrm{z}=136$ (their fragmentation is accompanied by the migration of $\mathrm{H}^{+}$), which in turn, later disintegrated into several low-molecular-weight splinter fragments at $\mathrm{m} / \mathrm{z} 109,108,82,81$, and 54 due to $\mathrm{HCN}$ and $\mathrm{CO}$ elimination from hypoxanthine (Figure 5). Consequently, the presence of two "heavy" fragments of ribose II $\left(\mathrm{C}_{5} \mathrm{H}_{9} \mathrm{O}_{4}\right)^{+}$at $\mathrm{m} / \mathrm{z}=136(46 \%)$ (instead of $\mathrm{m} / \mathrm{z}=133(41 \%)$ in the control) and hypoxanthine III $\left(\mathrm{C}_{5} \mathrm{H}_{4} \mathrm{ON}_{4}\right)^{+}$at $\mathrm{m} / \mathrm{z}=138(55 \%)$ (instead of $\mathrm{m} / \mathrm{z}=136(48 \%)$ in the control), as well as the peaks of low molecular weight splinter fragments formed from FAB-decomposition of hypoxanthine fragment at $\mathrm{m} / \mathrm{z}=111$ (49\%) (instead of $\mathrm{m} / \mathrm{z}=109(45 \%)$ in the control) and $\mathrm{m} / \mathrm{z}=84(43 \%)$ (instead of $\mathrm{m} / \mathrm{z}=82(41 \%)$ in the control) suggests that three deuterium atoms are incorporated into the ribose residue, and two other deuterium atoms - 
into the hypoxanthine residue of the inosine molecule (Figure 5). Such selective character of the deuterium inclusion into the inosine molecule on specific locations of the molecule was confirmed by the presence of deuterium in the smaller fission fragments.

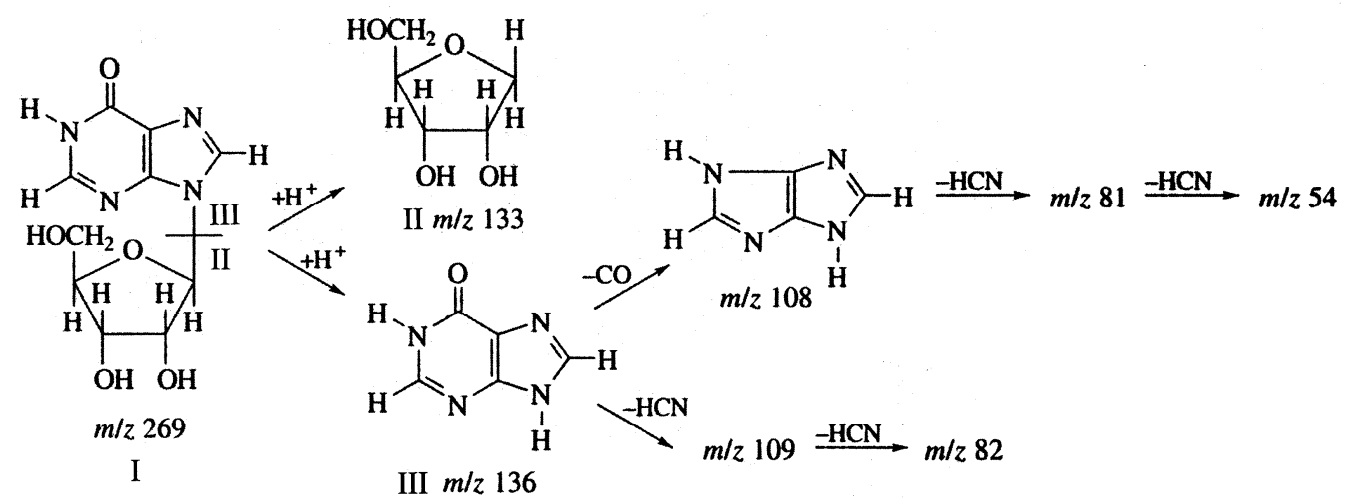

Figure 5: The fragmentation pathways of the inosine molecule leading to formation of smaller fragments by the FAB-method

The metabolic pathways of assimilation of glucose under aerobic conditions by chemoheterotrophic bacteria include the Embden-Meyerhof pathway; the anaerobic glycolysis is not widespred in this type of bacteria. When analyzing the level of deuterium enrichment of the inosine molecule we took into account the fact that the character of deuterium incorporation into the molecule is determined by the pathways of carbon assimilation (both glucose and amino acids). The carbon source was glucose as a main substrate and a mixture of deuterated amino acids from deuterated hydrolysate of methylotrophic bacterium B. methylicum as a source of deuterated substrates and amine nitrogen. Since the protons (deuterons) at positions of the ribose residue in the inosine molecule could have been originated from glucose, the character of deuterium inclusion into the ribose residue is mainly determined by the assimilation of glucose by glycolysis, associated with the Embden-Meyerhof pathway (Fig. 6). The decomposition of glucose into two molecules of pyruvate is carried out in 10 stages, the first five of which are a preparatory stage and the next 5 - the stage interfaced with the formation of ATP. During the glycolysis glucose is phosphorylated at hydroxyl group at the sixth carbon atom (C-6), forming glucose-6phosphate (step 1). Glucose 6-phosphate is then isomerized to fructose-6-phosphate (step 2), which is phosphorylated at the hydroxyl group at the first carbon atom, with the formation of fructose 1,6-bisphosphate (step 3). During both of these reactions of phosphorylation as a donor of phosphoryl group acts ATP. Next fructose-1,6-diphosphate is split into two three-carbon molecules - glyceroldehyde 3-phosphate and dihydroxyacetone phosphate (step 4), which in the result by means of several enzymatic reactions (5-10) is converted to piruvate (Fig. 6).

The overall equation of glycolysis:

$$
\text { Glucose }+2 \mathrm{NAD}^{+}+2 \mathrm{ADP}+2 \mathrm{P}_{i} \rightarrow 2 \text { piruvate }+2 \mathrm{NADH}+2 \mathrm{H}^{+}+2 \mathrm{ATP}+2 \mathrm{H}_{2} \mathrm{O},
$$

Most chemoheterotrophic bacteria from I group can grow under anaerobic conditions via fermentation of sugars (glycolysis), the main products of which are 2,3-butanediol, glycerol and $\mathrm{CO}_{2}$; besides are formed minor amounts of formed lactic acid and ethanol. This type of fermentation can be represented as follows:

$$
3 \text { mol. glucose } \rightarrow 2,3 \text {-butanediol }+2 \text { mol. glycerol }+4 \text { mol. } \mathrm{CO}_{2}
$$

Glucose is initially split via the Embden-Meyerhof pathway to glyceroldehyde 3-phosphate; after that there is branching pathway (Stanier et al., 1976). Some part of glyceroldehyde 3-phosphate is converted to dihydroxyacetone phosphate, while another part - to pyruvate, which is formed from 2,3-butanediol and $\mathrm{CO}_{2}$. Formation of 2,3-butanediol from pyruvate leads to the re-oxidation of the NADH formed during the conversion of glyceroldehyde 3-phosphate to pyruvate:

\section{2 mol. glyceroldehyde 3-phosphate +2 mol. $N A D^{+}+4$ mol. $A D P+2$ mol. $P \rightarrow 2$ mol. pyruvate +4 mol. ATP +2 mol. $N A D H+2$ mol. $H^{+}$,}




$$
2 \text { mol. pyruvate }+\mathrm{NADH}+\mathrm{H}^{+} \rightarrow 2 \text { mol. } \mathrm{CO}_{2}+2,3 \text {-butanediol }+\mathrm{NAD}^{+} .
$$

The redox equilibrium is maintained by the concomitant restoration of glyceroldehyde 3-phosphate to glycerol:

$$
\text { Glyceroldehyde 3-phosphate }+\mathrm{NAD} H+\mathrm{H}^{+} \rightarrow \text { Glycerol }+\mathrm{P}+\mathrm{NAD} \text {. }
$$

B. subtilis cannot grow under anaerobic conditions due to the use of glucose, probably because of the inability to recover glyceroldehyde 3-phosphate to glycerol (Stanier et al., 1976); in aerobic conditions, this bacterium ferments glucose to form large amounts of 2,3-butanediol.

Since glucose in our experiments was used in a protonated form, its contribution to the level of deuterium enrichment of the ribose residue was neglected. However, as the investigation of deuterium incorporation into the molecule by FAB method showed that deuterium was incorporated into the ribose residue of the inosine molecule owing to enzymatic isomerization of glucose in ${ }^{2} \mathrm{H}_{2} \mathrm{O}$ medium.

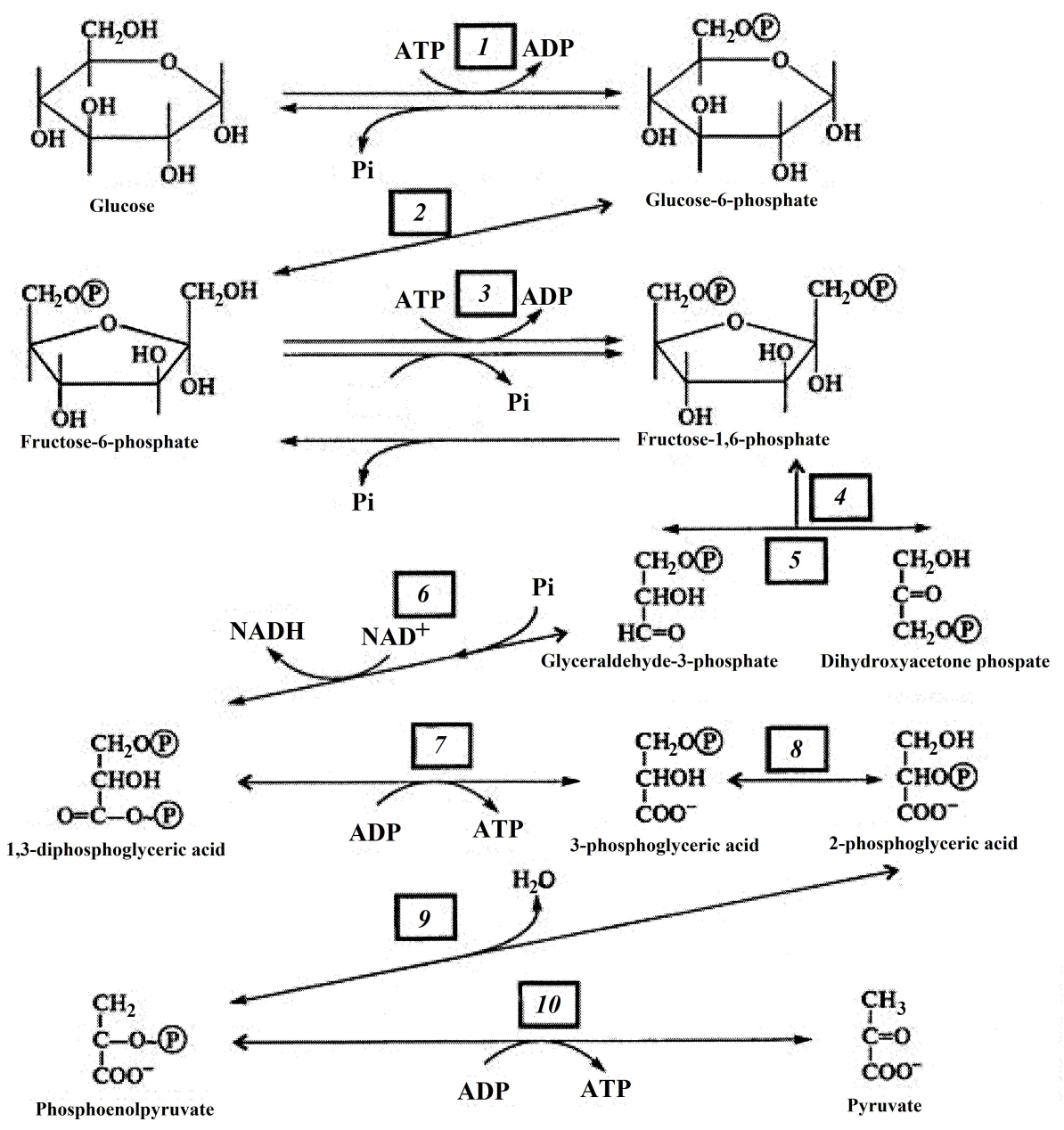

Figure 6: The Embden-Meyerhof pathway of glycolysis: 1 - hexokinase; 2 - glucose-6-phosphate izomerase; 3 phosphofructokinase-1; 5 - fructose-1,6-bisphosphate aldolase; 6 - triosephosphate isomerase; 7 -

glyceraldehyde-3-phosphat dehydrogenase; 8 - phosphoglycerate kinase; 9 - phosphoglycerate mutase; 10 enolase; 11 - pyruvate kinase. Total reaction: Glucose $+2 \mathrm{NAD}^{+}+2 \mathrm{ADP}+2 \mathrm{P}_{\mathrm{i}} \rightarrow 2$ piruvate $+2 \mathrm{NADH}+2 \mathrm{H}^{+}+$ $2 \mathrm{ATP}+2 \mathrm{H}_{2} \mathrm{O}$ (adapted from Stryer R.Y, 1995)

The numerous isotopic ${ }^{1} \mathrm{H}-{ }^{2} \mathrm{H}$ exchange processes could also have led to specific incorporation of deuterium atoms at certain positions in the inosine molecule. Such accessible positions in the inosine molecule are hydroxyl $\left(\mathrm{OH}^{-}\right)-\left(\mathrm{C}^{\prime} 2, \mathrm{C}^{\prime} 3\right.$-positions in the ribose residue) and imidazole protons at $\mathrm{NH}^{+}$heteroatoms (N1-position in the 
hypoxanthine residue), which can be easily exchanged on deuterium in ${ }^{2} \mathrm{H}_{2} \mathrm{O}$ via keto-enol tautomerism. Three non-exchangeable deuterium atoms in the ribose residue of inosine are synthesized de novo and could have been originated via enzymatic assimilation of glucose by the cell, while two other deuterium atoms at C2,C8-positions in the hypoxanthine residue could be synthesized de novo at the expense of $\left[{ }^{2} \mathrm{H}\right]$ amino acids as glycine, glutamine and aspartate (with participation of $\mathrm{N}^{10}-\mathrm{CHO}-\mathrm{FH}_{4}$ and $\mathrm{N}^{5}, \mathrm{~N}^{10}-\mathrm{CH}=\mathrm{FH}_{4}$ ) (Fig. 7), that originated from the deuterated hydrolysate of methylotrophic bacterium $B$. methylicum obtained on $98 \%$ of ${ }^{2} \mathrm{H}_{2} \mathrm{O}$ medium. A glycoside proton at $\beta-\mathrm{N}_{9}$-glycosidic bond could be replaced with deuterium via the reaction of $\mathrm{CO}_{2}$ elimination at the stage of the ribulose-5-monophosphate formation from 3-keto-6-phosphogluconic acid with the subsequent proton (deuteron) attachment at the $\mathrm{C} 1$-position of ribulose-5-monophosphate. In general, our studies confirmed this scheme (Ignatov \& Mosin, 2013c). However, it should be noted that auxotrophy of this mutant strain in tyrosine, histidine, adenine and uracil as well as the enzymatic synthesis of a precursor of inosine, inosine-5monophospate (IMP) from ribose-5-monophosphate and amino acids presupposes the branched metabolic pathways, different from those described above. Since it is known, that intermediates in glycolysis are precursors to a number of compounds as nucleotides and amino acids.

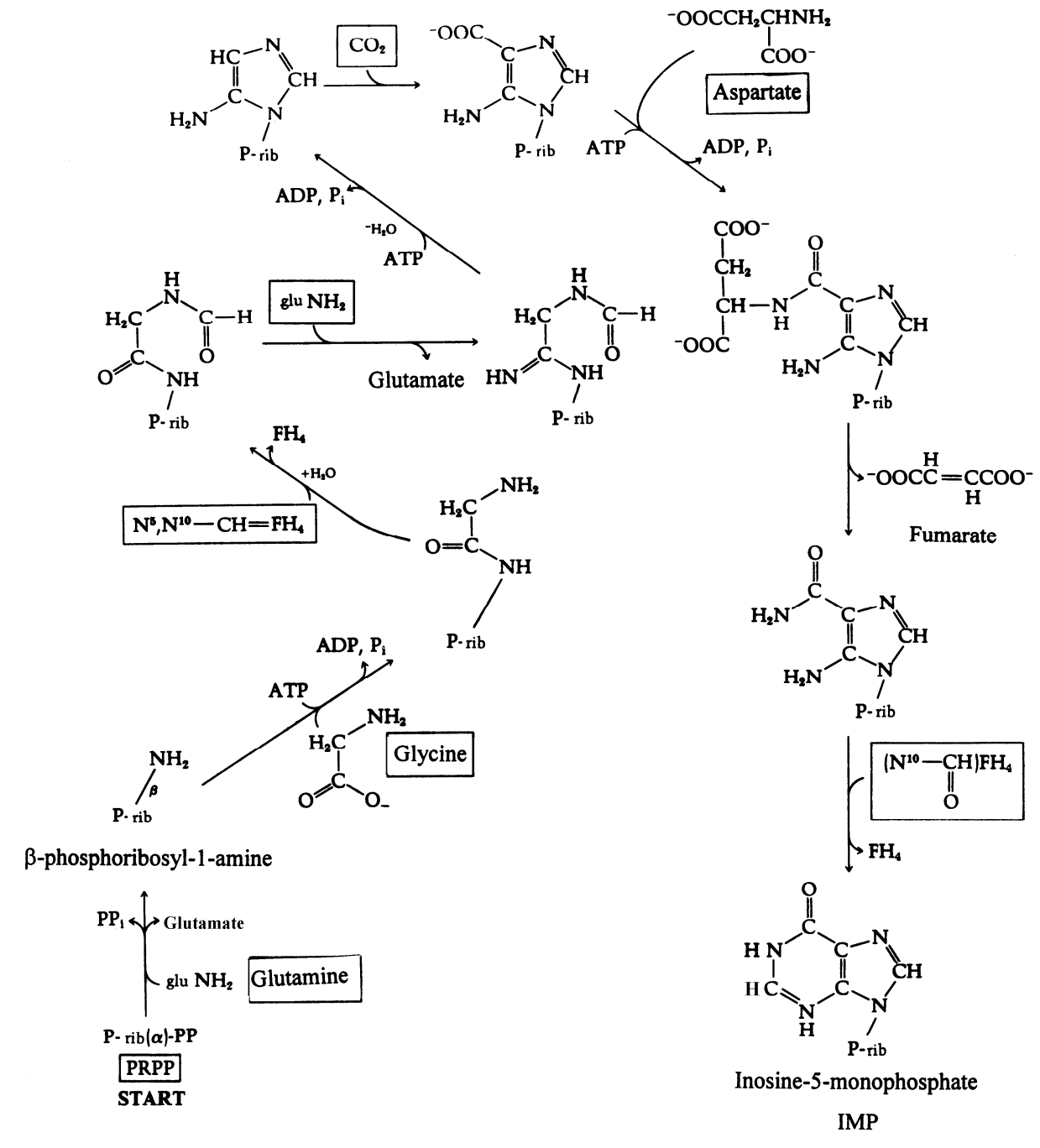

Figure 7: Overall scheme of biosynthesis of IMP by microbial cell (adapted from Bohinski, 1983)

Our experiments demonstrated that chemo-heterotrophic metabolism does not undergo significant changes in ${ }^{2} \mathrm{H}_{2} \mathrm{O}$. This testifies about a phenotypic nature of adaptation to ${ }^{2} \mathrm{H}_{2} \mathrm{O}$ phenomenon as the adapted cells eventually return back to the normal growth after some lag-period after their replacement back onto $\mathrm{H}_{2} \mathrm{O}$-medium. However, the effect of reversion of growth on $\mathrm{H}_{2} \mathrm{O} /{ }^{2} \mathrm{H}_{2} \mathrm{O}$ media does not exclude an opportunity that a certain genotype determines the manifestation of the same phenotypic attribute in ${ }^{2} \mathrm{H}_{2} \mathrm{O}$-media with high deuterium content. At placing a cell onto ${ }^{2} \mathrm{H}_{2} \mathrm{O}$-media lacking protons, not only ${ }^{2} \mathrm{H}_{2} \mathrm{O}$ is removed from a cell due to isotopic $\left({ }^{1} \mathrm{H}-{ }^{2} \mathrm{H}\right)$ exchange, but also there are occurred a rapid isotopic $\left({ }^{1} \mathrm{H}_{-}{ }^{2} \mathrm{H}\right)$ exchange in hydroxyl (-OH), sulfohydryl 
$(-\mathrm{SH})$ and amino $\left(-\mathrm{NH}_{2}\right)$ groups in all molecules of organic substances, including proteins, nucleic acids, carbohydrates and lipids. It is known, that in these conditions only covalent $\mathrm{C}-\mathrm{H}$ bond is not exposed to isotopic $\left({ }^{1} \mathrm{H}-{ }^{2} \mathrm{H}\right)$ exchange and, thereof only molecules with bonds such as $\mathrm{C}-{ }^{2} \mathrm{H}$ can be synthesized de novo (Mosin et al., 1996b; Mosin \& Ignatov, 2012a). Thus, the most sensitive to replacement of $\mathrm{H}$ on ${ }^{2} \mathrm{H}$ are the apparatus of biosynthesis of macromolecules and a respiratory chain, i.e., those cellular systems using high mobility of protons and high speed of breaking up of hydrogen bonds. Last fact allows consider adaptation to ${ }^{2} \mathrm{H}_{2} \mathrm{O}$ as adaptation to the nonspecific factor affecting simultaneously the functional condition of several numbers of cellular systems: metabolism, ways of assimilation of carbon substrates, biosynthetic processes, and transport function, structure and functions of macromolecules.

The primary organisms (eobionts) were according to modern modern concepts heterotrophs, feeding by abiogenic organic substances (Koch, 1998). In the process of life they emitted carbon dioxide, enriching the atmosphere. The atmosphere at that time was predominantly carbonic and did not contain oxygen. The first living organisms on Earth evidently originated in anaerobic conditions, when the primitive ocean was rich in organic matter formed at earlier stages of evolution (Mosin \& Ignatov, 2014; Mosin \& Ignatov, 2015). The wide occurrence of glycolysis in bacteria indicates that it is one of the most ancient metabolic pathways (Romano \& Conway, 1996). The biochemical reactions of glycolysis and its parallel pathway, the pentose phosphate pathway, widespread in methylotrophs, occur metal-catalyzed under the oxygen-free conditions of the Archean ocean, and, probably, also in the absence of enzymes (Keller et al., 2014). Glycolysis could thus have originated because of chemical limitations of the prebiotic world.

The main metabolic pathways as glycolysis and Krebs cycle are present in all living organisms and characterized to the universal common ancestor that was a prokaryote with combined amino acid, nucleotide, carbohydrate and lipid metabolism (Smith \& Morowitz, 2004; Ebenhöh \& Heinrich, 2001; Meléndez-Hevia et al., 1996). The preservation of these ancient pathways in evolution may result from the fact that these reactions are optimal for solving specific problems with metabolism. Thus, the end products of glycolysis and Krebs cycle are being formed with high efficiency and with a minimum number of steps. The first metabolic pathways based on enzymes might have been part of a purine nucleotide metabolism (Romano \& Conway, 1996).

The oxygen-rich biosphere arose much later, about 2 billion years ago. This important geochemical revolution in evolution is explained by photosynthesis. With such a character of the evolution the aerobic chemo-autotrophs could appear only after oxygenic photosynthesis had been evolved. It can be assumed that chemo-autotrophs and chemo-heterotrophs could have evolved from common prokaryotic microorganisms precursors that carry out photosynthesis, but lost the photosynthesis apparatus, and their electron transport chain functioning in photosynthesis, began to carry out a new feature of assimilation of carbon compounds. Some contemporary representatives of the two major groups of prokaryotes, photosynthetic and non-photosynthetic ones, have very peculiar properties. These include the existence of several complex characteristic of these types of systems of internal membranes; absence of a functioning of tricarboxylic acid cycle; availability of the Calvin cycle, or its analogue, the pentose phosphate cycle; localization in carboxysomes the key enzyme of the Calvin cycle (ribulose diphosphate carboxylase) (Ouzounis \& Kyrpides, 1996; Schmidt et al., 2003). Recent studies suggest the role of chemo-heterotrophs in the evolution of microorganisms (Ignatov \& Mosin, 2013b).

Eukaryotic cells apparently arose only when there was oxygen in the atmosphere. All eukaryotes, with very few exceptions, are aerobic organisms. Prokaryotes occupy many different ecological niches. The development of various types of metabolism in prokaryotes was apparently due to a simple cell structure, highly regulation systems, a rapid growth and the presence of multiple gene transfer mechanisms. On the path of further evolution of prokaryotes there were insurmountable difficulties related primarily to the small size of the genome, its haploid state and the small size of the cells. The new environment with aerobic conditions allows to obtain more energy, but to its use it was needed larger cells, extensive structural differentiation and therefore on many times greater gene. Large and small biological molecules provide the biosynthesis, metabolism and bioenergetics. The wastes of primary protozoa were compounds such as lactic acid and ethanol. These compounds had much less energy consumption compared to carbohydrates, but they were able to release a large amount of energy if fully oxidized to $\mathrm{CO}_{2}$ and $\mathrm{H}_{2} \mathrm{O}$. As a result of the evolution originated new living organisms capable to fix oxygen in the form of $\mathrm{H}_{2} \mathrm{O}$ and $\mathrm{CO}_{2}$, and in return to receive the energy of combustion of what was formerly their waste.

Metabolic processes that occur with the participation of oxygen (primarily oxidative phosphorylation in breathing), and relatively few are evolutionarily later than anaerobic processes. In the absence of oxygen, it is impossible to complete combustion (oxidation) of the organic molecules of nutrients. However, as was demonstrated by the properties of the currently existing anaerobic cells, the essential for life energy is being obtained in the course of redox processes. In aerobic systems the final acceptor (oxidizing agent) of hydrogen serves oxygen, while in anaerobic - other substances. Oxidation without oxygen is implemented in two fermentation pathways - glycolysis and alcoholic fermentation. Glycolysis consists in splitting of multistage hexoses up to two molecules of pyruvate (pyruvic acid) containing three carbon atoms. In this way the two molecules of NAD reduced to NADH and two molecules of ADP phosphorylated to get two molecules of ATP. 
The comparison of existing metabolic pathways of amino acids with the genetic code reveals that a metabolically related amino acids correlate well with respect to their codon. This makes it a very attractive idea of parallel evolution of the genetic code and metabolism and indicates the presence of the hierarchy of amino acids. More simple amino acids such as Gly, Ser, Ala, Asp and Glu are considered earlier in contrast to the more complex amino acids, as Met, His and Asn. However, consistent appearance of amino acids does not reflected in the existing protein structures, since amino acid residues of proteins to some extent are interchangeable, so the correlation with early life periods is currently hardly justified (Ignatov \& Mosin, 2013c).

\subsection{Possible Conditions for Origin of First Organic Forms in Hot Mineral Water with HDO}

Biological experiments with ${ }^{2} \mathrm{H}_{2} \mathrm{O}$ allow to better prognosticate the conditions under which life and living matter had evolved (Ignatov, 2010; Ignatov, 2012). The mineral composition of the water $\left(\mathrm{Ca}^{2+}, \mathrm{Mg}^{2+}, \mathrm{Zn}^{2+}, \mathrm{Mn}^{2+}, \mathrm{K}^{+}\right.$, $\left.\mathrm{Na}^{+}, \mathrm{SO}_{4}{ }^{2-}, \mathrm{Cl}^{-}\right)$, the isotopic composition, the $\mathrm{pH}$ value and temperature appear to play a significant role in evolution of first organic forms (Ignatov \& Mosin, 2013a). Most better to these conditions satisfy karst water and seawater. Circulating in bowels of cracks, crevices, channels and caves karst waters are enriched with $\mathrm{Ca}\left(\mathrm{HCO}_{3}\right)_{2}$ and other minerals, actively cooperating with living matter. Once appeared in these waters the process of self-organization of primary organic forms in water solutions might be supported by thermal energy of magma, volcanic activity and solar radiation.

We have conducted experiments for the testing of various samples of mineral water from karst springs and sea water from Bulgaria and the cactus juice of Echinopsis pachanoi with IR-spectroscopy and Differential Nonequilibrium Energy Spectrum (DNES) method relative to the control - deionized water. The cactus is chosen as a model system because it contains approximately $90 \%$ (w/w) $\mathrm{H}_{2} \mathrm{O}$ (Table 4).

Table 4: Characteristics of spectra of water of various origin obtained by the DNES-method*

\begin{tabular}{|c|c|c|c|c|}
\hline \multicolumn{2}{|c|}{$-\mathrm{E}, \mathrm{eV}$} & \multirow{2}{\lambda,}{} & $\mathrm{k}$, \\
\hline Cactus juice & $\begin{array}{c}\text { Mineral water } \\
\text { from Rupite } \\
\text { Village (Bulgaria) }\end{array}$ & Seawater & $\mathrm{cm}^{-1}$ \\
\hline 0.1112 & 0.1112 & - & 11.15 & 897 \\
\hline 0.1187 & 0.1187 & - & 10.45 & 957 \\
\hline 0.1262 & 0.1262 & - & 9.83 & 1017 \\
\hline 0.1287 & 0.1287 & - & 9.64 & 1037 \\
\hline 0.1362 & - & 0,1362 & 9.10 & 1099 \\
\hline 0.1387 & 0.1387 & - & 8.95 & 117 \\
\hline
\end{tabular}

Notes:

*The function of the distribution of energies $\Delta \mathrm{f}$ among individual $\mathrm{H}_{2} \mathrm{O}$ molecules was measured in reciprocal electron volts $\left(\mathrm{eV}^{-1}\right)$. It is shown at which values of the spectrum $-\mathrm{E}(\mathrm{eV})$ are observed the biggest local maximums of this function; $\lambda$ - wave length; $\kappa$ - wave number.

For calculation of the function $f(E)$ which represents the energy spectrum of water, the experimental dependence between the wetting angle $(\theta)$ and the energy of hydrogen bonds $(E)$ is established:

where $b=14,33 \mathrm{eV}^{-1}$

$$
f(E)=\frac{14,33 f(\theta)}{\left[1-(1+b E)^{2}\right]^{2}},
$$

The relation between the wetting angle $(\theta)$ and the energy $(E)$ of the hydrogen bonds between $\mathrm{H}_{2} \mathrm{O}$ molecules is calculated by the formula:

$$
\theta=\operatorname{arcos}(-1-14,33 E)
$$

According to the experimental data the closest to the DNES-spectrum of cactus juice (Fig. 8, curve 1) was the DNES-spectrum of mineral water contacting $\mathrm{Ca}^{2+}$ and $\mathrm{HCO}_{3}{ }^{-}$ions (Fig. 8, curve 2). DNES-spectra of cactus juice and mineral water have magnitudes of local maximums at $E=-0.1112 ;-0.1187 ;-0.1262 ;-0.1287$ and $0.1387 \mathrm{eV}$. Similar local maximums in the DNES-spectrum between cactus juice and seawater were detected at $E=-0.1362 \mathrm{eV}$. The DNES-spectrum of the control sample of deionized water (Fig. 8, curve 5) was substantially different from the spectra of seawater and mineral water. 
Another important parameter was measured by the DNES method - the average energy $\left(\Delta \mathrm{E}_{\mathrm{H} \ldots \mathrm{o}}\right)$ of hydrogen H...O-bonds among individual molecules $\mathrm{H}_{2} \mathrm{O}$, which makes up $-0,1067 \pm 0,0011 \mathrm{eV}$. When the water temperature is changed, the average energy of hydrogen H...O-bonds alternates. This testified about the restructuring of average energies among individual $\mathrm{H}_{2} \mathrm{O}$ molecules with a statistically reliable increase of local maximums in DNES-spectra.

\section{Dr. Ignatov, Dr. Mosin, 2010}

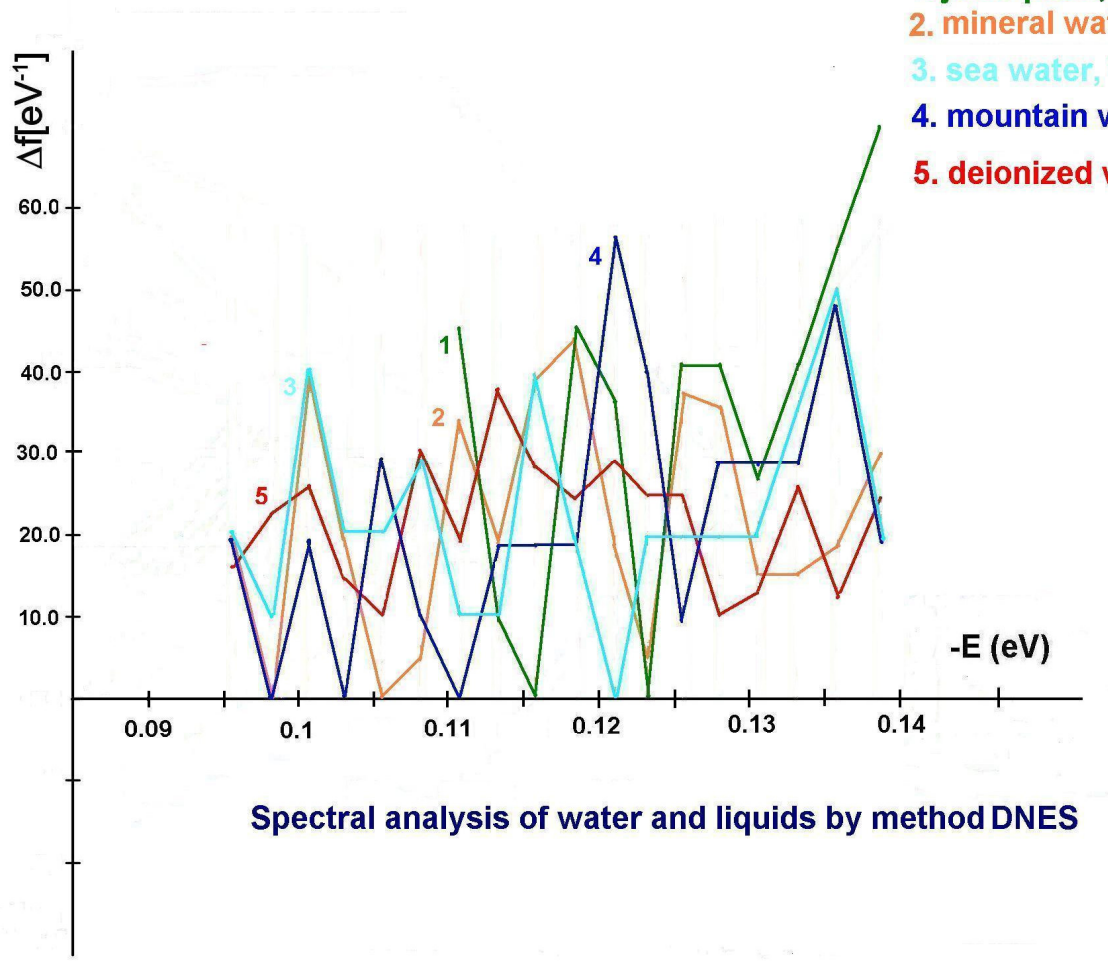

1. juice plant, cactus

2. mineral water, Rupite

4. mountain water, Teteven

\section{5. deionized water}

Figure 8: DNES-spectra of water samples of various origin: 1 - cactus juice; 2 - mineral water from Rupite village (Bulgaria); 3 - seawater (Varna, Bulgaria); 4 - mountain water (Teteven, Bulgaria); 5 - deionized water (the control)

As shown from these data, the closest to the IR-spectrum of cactus juice was mineral water from Rupite Village (Bulgaria), which DNES and IR spectrum is shown in Fig. 8 and Fig. 9 (Thermo Nicolet Avatar 360 Fouriertransform IR). IR-spectra of cactus juice and mineral water with $\mathrm{HCO}_{3}{ }^{-}(1320-1488 \mathrm{mg} / \mathrm{l}), \mathrm{Ca}^{2+}(29-36 \mathrm{mg} / \mathrm{l})$, $\mathrm{pH}$ (6.85-7.19), have local maximums at $\lambda=8.95 ; 9.67 ; 9.81 ; 10.47$ and $11.12 \mu \mathrm{m}$ (Fourier-IR spectrometer Brucker Vertex). Common local maximums in the IR-spectrum between cactus juice and seawater are detected at $\lambda=9.10 \mu \mathrm{m}$. The local maximums obtained with the IR method at $\lambda=9.81 \mu \mathrm{m}\left(k=1019 \mathrm{~cm}^{-1}\right)$ and $\lambda=8.95$ $\mu \mathrm{m}\left(k=1117 \mathrm{~cm}^{-1}\right)$ (Thermo Nicolet Avatar 360 Fourier-transform IR) are located on the spectral curve of the local maximum at $\lambda=9.7 \mu \mathrm{m}\left(k=1031 \mathrm{~cm}^{-1}\right)$ (Fig. 9). With the DNES method were obtained the following results $-8.95 ; 9.10 ; 9.64 ; 9.83 ; 10.45$ and $11.15 \mu \mathrm{m}$ ( $\lambda$, wavelength), or $897 ; 957 ; 1017 ; 1037 ; 1099$ and 1117 $\mathrm{cm}^{-1}$ ( $k$, wave numbers). 


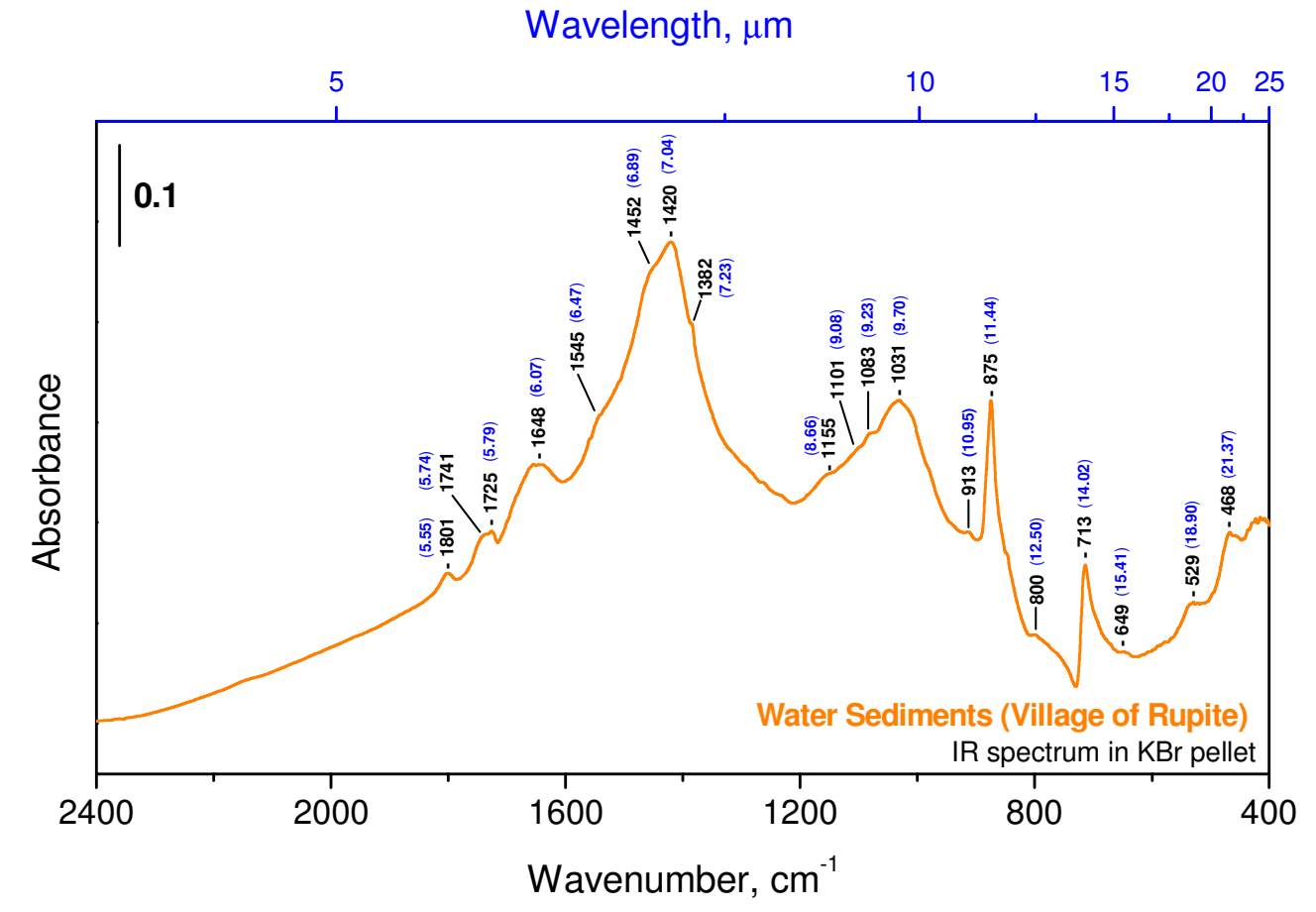

Figure 9: IR-spectrum of water obtained from Rupite Village (Bulgaria)

Such a character of IR- and DNES-spectra and distribution of local maximums may prove that hot mineral alkaline water having the most likeness in the characters of DNES- and IR-spectra and its characteristics with cactus juice is preferable for origin and maintenance of life compared to other types of water analyzed by these methods. Thus, in hot mineral waters the local maximums in the IR-spectrum are more manifested compared to the local maximums obtained in the IR-spectrum of the same water at a lower temperature. The difference in the local maximums from $+20{ }^{0} \mathrm{C}$ to $+95{ }^{0} \mathrm{C}$ at each $+5{ }^{0} \mathrm{C}$ according to the Student $t$-criterion makes up $-\mathrm{p}<0.05$. These data indicate that the origination of life and living matter depends on the structure and physical chemical properties of water, as well as its temperature and $\mathrm{pH}$ value. The most closed to the IR- and DNES-spectrum of water, which contains bicarbonates and $\mathrm{Ca}^{2+}$ ions typical for the formation of stromatolites, the dolomite layered acretionary structures formed in shallow seawater by colonies of cyanobacteria, is the IR-spectrum of cactus juice. For this reason cactus juice was applied as a model system. The most closed to local maximums in IRspectrum of cactus juice are local maximums in IR-spectra of alkaline mineral water interacting with $\mathrm{CaCO}_{3}$ and then seawater. In connection with these data the following reactions participating with $\mathrm{CaCO}_{3}$ in aqueous solutions are important:

$$
\begin{aligned}
& \mathrm{CO}_{2}+4 \mathrm{H}_{2} \mathrm{~S}+\mathrm{O}_{2}=\mathrm{CH}_{2} \mathrm{O}+4 \mathrm{~S}+3 \mathrm{H}_{2} \mathrm{O} \\
& \mathrm{CaCO}_{3}+\mathrm{H}_{2} \mathrm{O}+\mathrm{CO}_{2}=\mathrm{Ca}\left(\mathrm{HCO}_{3}\right)_{2} \\
& \mathrm{CO}_{2}+\mathrm{OH}^{-}=\mathrm{HCO}_{3}^{-} \\
& 2 \mathrm{HCO}_{3}^{-}+\mathrm{Ca}^{2+}=\mathrm{CaCO}_{3}+\mathrm{CO}_{2}+\mathrm{H}_{2} \mathrm{O}
\end{aligned}
$$

The equation (3) shows how some chemosynthetic bacteria use energy from the oxidation of $\mathrm{H}_{2} \mathrm{~S}_{\text {and }} \mathrm{CO}_{2}$ to $\mathrm{S}$ and formaldehyde $\left(\mathrm{CH}_{2} \mathrm{O}\right)$. The equation (4) is related to one of the most common processes in nature: in the presence of $\mathrm{H}_{2} \mathrm{O}$ and $\mathrm{CO}_{2}, \mathrm{CaCO}_{3}$ transforms into $\mathrm{Ca}\left(\mathrm{HCO}_{3}\right)_{2}$. In the presence of hydroxyl $\mathrm{OH}^{-}$ions, $\mathrm{CO}_{2}$ transforms into $\mathrm{HCO}_{3}{ }^{-}$(equation (5). Equation (6) is valid for the process of formation of the stromatolites - the dolomite layered acretionary structures formed in shallow seawater by colonies of cyanobacteria. In $2010 \mathrm{D}$. Ward described fossilized stromatolites in the Glacier National Park (USA) (Schirber, 2010). Stromatolites aged 3.5 billion years had lived in warm and hot water in zones of volcanic activity, which could be heated by magma. This suggests that the first living forms evidently evolved in hot geysers (Ponsa et al., 2011). It is known that water in geysers is rich in carbonates, while the temperature is ranged from $+100{ }^{\circ} \mathrm{C}$ to $+150{ }^{0} \mathrm{C}$. In 2011 a team of Japanese scientists under the leadership of T. Sugawara showed that life originated in warm or, more likely, hot water (Sugawara, 2011; Kurihara et al., 2011). From aqueous solution of organic molecules, DNA and synthetic enzymes were created proto cells. For this the initial solution was heated to a temperature close to water's boiling point $+95{ }^{0} \mathrm{C}$. Then its temperature was lowered to $+65{ }^{0} \mathrm{C}$ with formation of proto cells with 
primitive membrane. This laboratory experiment is an excellent confirmation of the possibility that life originated in hot water.

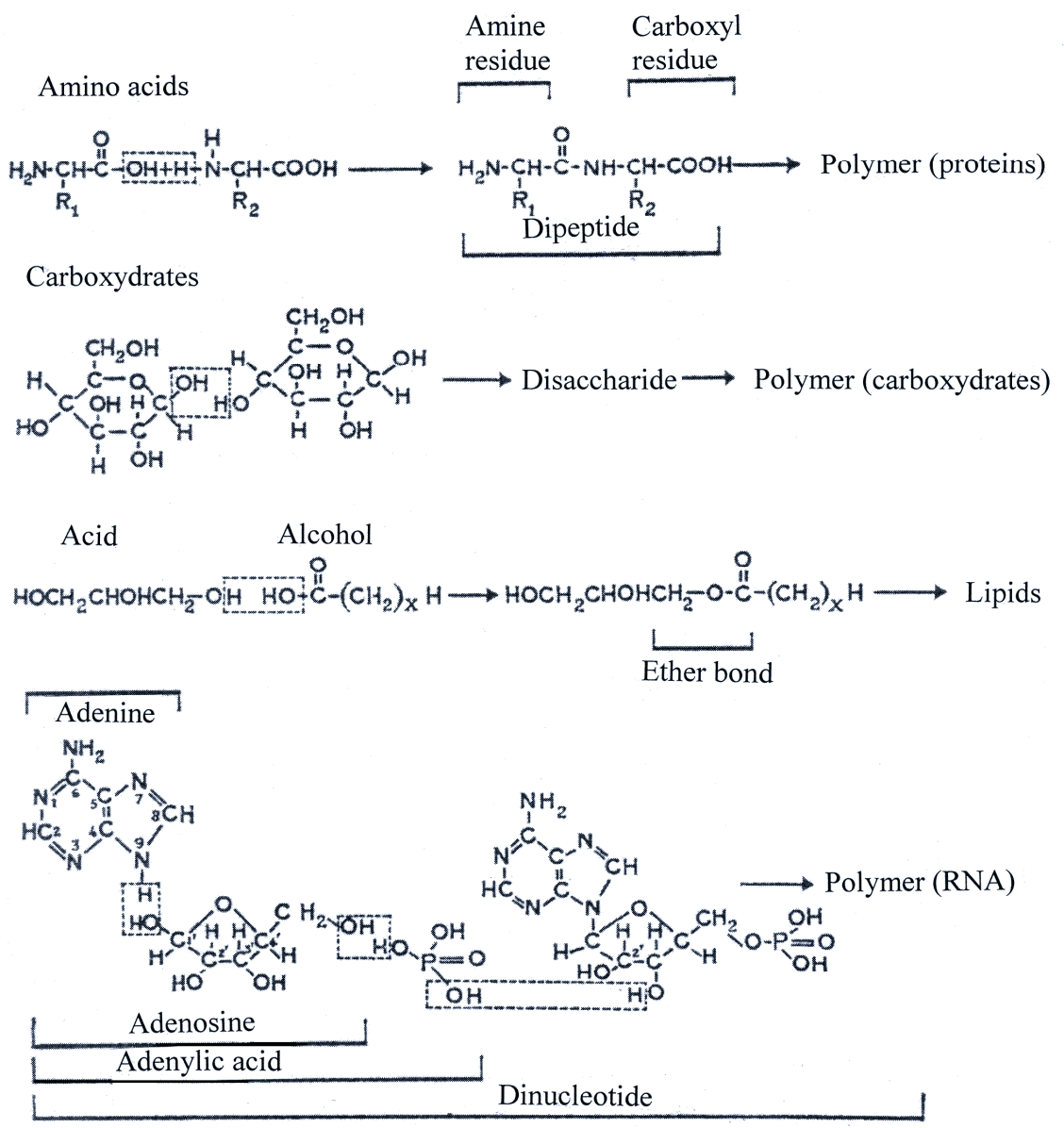

Figure 10: Reactions of condensation and dehydration in alkaline conditions with $\mathrm{pH}=9-10$ catalyzed by $\mathrm{HCN}$ and its derivatives, resulting in synthesis from separate molecules larger organic molecules of polymers. The top three equations: condensation and the subsequent polymerization of amino acids in proteins; carbohydrates - in polycarboxydrates and acids and ethers - into lipids. The bottom equation - condensation of adenine with ribose and $\mathrm{H}_{3} \mathrm{PO}_{4}$, leading to formation of dinucleotide

Analyzing the experimental data the prognosis was made to predict a possible transition from synthesis of small organic molecules under high temperatures to more complex organic molecules as proteins. There are reactions of condensation-dehydration of amino acids into separate blocks of peptides that occur under alkaline conditions, with $\mathrm{pH}=9-11$. The important factor in reaction of condensation of two amino acid molecules into the dipeptide is allocation of $\mathrm{H}_{2} \mathrm{O}$ molecule when a peptide chain is formed, as the reaction of polycondensation of amino acids is accompanied by dehydration, the $\mathrm{H}_{2} \mathrm{O}$ removal from reaction mixture speeds up the reaction rates. This testifies that formation of early organic forms may have occured nearby active volcanoes, because at early periods of geological history volcanic activity occurred more actively than during subsequent geological times. However, dehydratation accompanies not only amino acid polymerization, but also association of other small blocks into larger organic molecules, and also polymerization of nucleotides into nucleic acids. Such association is connected with the reaction of condensation, at which from one block a proton is removed, and from another a hydroxyl group with the formation of $\mathrm{H}_{2} \mathrm{O}$ molecule.

In 1969 the possibility of existence of condensation-dehydration reactions under conditions of primary hydrosphere was proven by M. Calvin (Calvin, 1969). From most chemical substances hydrocyanic acid (HCN) and its derivatives - cyanoamid $\left(\mathrm{CH}_{2} \mathrm{~N}_{2}\right)$ and dicyanoamid $\left(\mathrm{HN}(\mathrm{CN})_{2}\right)$ possess dehydration ability and the ability to catalyze the process of linkage of $\mathrm{H}_{2} \mathrm{O}$ from primary hydrosphere (Mathews \& Moser, 1968). The presence of $\mathrm{HCN}$ in primary hydrosphere was proven by S. Miller's early experiments (Miller, 1953). Chemical reactions with $\mathrm{HCN}$ and its derivatives are complex with a chemical point of view; in the presence of $\mathrm{HCN}, \mathrm{CH}_{2} \mathrm{~N}_{2}$ and $\mathrm{HN}(\mathrm{CN})_{2}$ the condensation of separate blocks of amino acids accompanied by dehydration, can proceed at 
normal temperatures in strongly diluted $\mathrm{H}_{2} \mathrm{O}$-solutions. These reactions show the results of synthesis from separate smaller molecules to larger organic molecules of polymers, e.g. proteins, polycarboxydrates, lipids, and nucleic acids (Fig. 10). Furthermore, polycondensation reactions catalyzed by HCN and its derivatives depend on acidity of water solutions in which they proceed (Abelson, 1966). In acid aqueous solutions with $\mathrm{pH}=4-6$ these reactions do not occur, whereas alkaline conditions with $\mathrm{pH}=9-10$ promote their course. There has not been unequivocal opinion, whether primary water was alkaline, but it is probable that such $\mathrm{pH}$ value possessed mineral waters adjoining with basalts, i.e. these reactions could occur at the contact of water with basalt rocks, that testifies our hypothesis. It may be supposed that primary water might contain more deuterium at early stages of life evolution, and deuterium was distributed non-uniformly in hydrosphere and atmosphere (Ignatov \& Mosin, 2012). The reason of this is that the primary atmosphere of the Earth was reductive, without $\mathrm{O}_{2}-\mathrm{O}_{3}$ layer protecting the Earth surface from rigid short-wave solar radiation carrying huge energy. This simplifies radiation to freely pass through $\mathrm{O}_{2}$-free atmosphere and reaching hydrosphere, may be the cause of further radiolysis and photolysis of water. Energy of radiation, volcanic geothermal processes on a hot Earth surface and electric discharges in atmosphere, could lead to the accumulation of deuterium in hydrosphere in the form of $\mathrm{H}^{2} \mathrm{HO}$ that evaporates more slowly that $\mathrm{H}_{2} \mathrm{O}$, but condenses faster. This fact may make inprint on thermostability of deuterated macromolecules as the covalent bonds formed with ${ }^{2} \mathrm{H}$ are stronger than those formed with hydrogen. It should be noted, that geothermal sources might be used for synthesis of various organic molecules. Thus, amino acids were detected in solutions of formaldehyde $\mathrm{CH}_{2} \mathrm{O}$ with hydroxylamine $\mathrm{NH}_{2} \mathrm{OH}$, formaldehyde with hydrazine $\left(\mathrm{N}_{2} \mathrm{H}_{4}\right)$ in water solutions with $\mathrm{HCN}$, after heating of a reactionary mixture to $+95{ }^{0} \mathrm{C}$ (Harada \& Fox, 1964). In model experiments reaction products were polymerized into peptide chains, that is the important stage towards inorganic synthesis of protein. In a reactionary mixture with a $\mathrm{HCN}-\mathrm{NH}_{3}$ solution in water were formed purines and pyrimidines (Fig. 11). In other experiments amino acid mixtures were subjected to influence of temperatures from $+60{ }^{0} \mathrm{C}$ up to $+170{ }^{0} \mathrm{C}$ with formation of short protein-like molecules resembling early evolutionary forms of proteins subsequently designated as thermal proteinoids. They consisted of 18 amino acids usually occurring in protein hydrolyzates. The synthesized proteinoids are similar to natural proteins on a number of other important properties, e. g. on linkage by nucleobases and ability to cause the reactions similar to those catalyzed by enzymes in living organisms as decarboxylation, amination, deamination, and oxidoreduction. Proteinoids are capable to catalytically decompose glucose (Fox \& Krampitz, 1964) and to have an effect similar to the action of $\alpha$-melanocyte-stimulating hormone (Fox \& Wang, 1968). The best results on polycondensation were achieved with the mixes of amino acids containing aspartic and glutamic acids, which are essential amino acids occurring in all modern living organisms. Under certain conditions in hot mixture of proteinoids in water solutions are formed elementary structures like proteinoid microspheres with diameter 5-10 $\mu \mathrm{m}$ (Nakashima, 1987).<smiles>N=C(N)c1ncncn1</smiles><smiles>Nc1ncnc2[nH]cnc12</smiles>

Adenine<smiles>NCCCNCCn1cnc(C(N)=O)c1N</smiles>

4-Aminoimidazole-5-<smiles>Nc1nc(O)c2nc[nH]c2n1</smiles>

Guanine<smiles>Oc1ncnc2[nH]cnc12</smiles>

Hypoxanthine

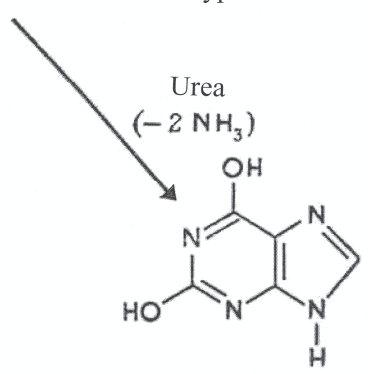

Xanthine

a) 


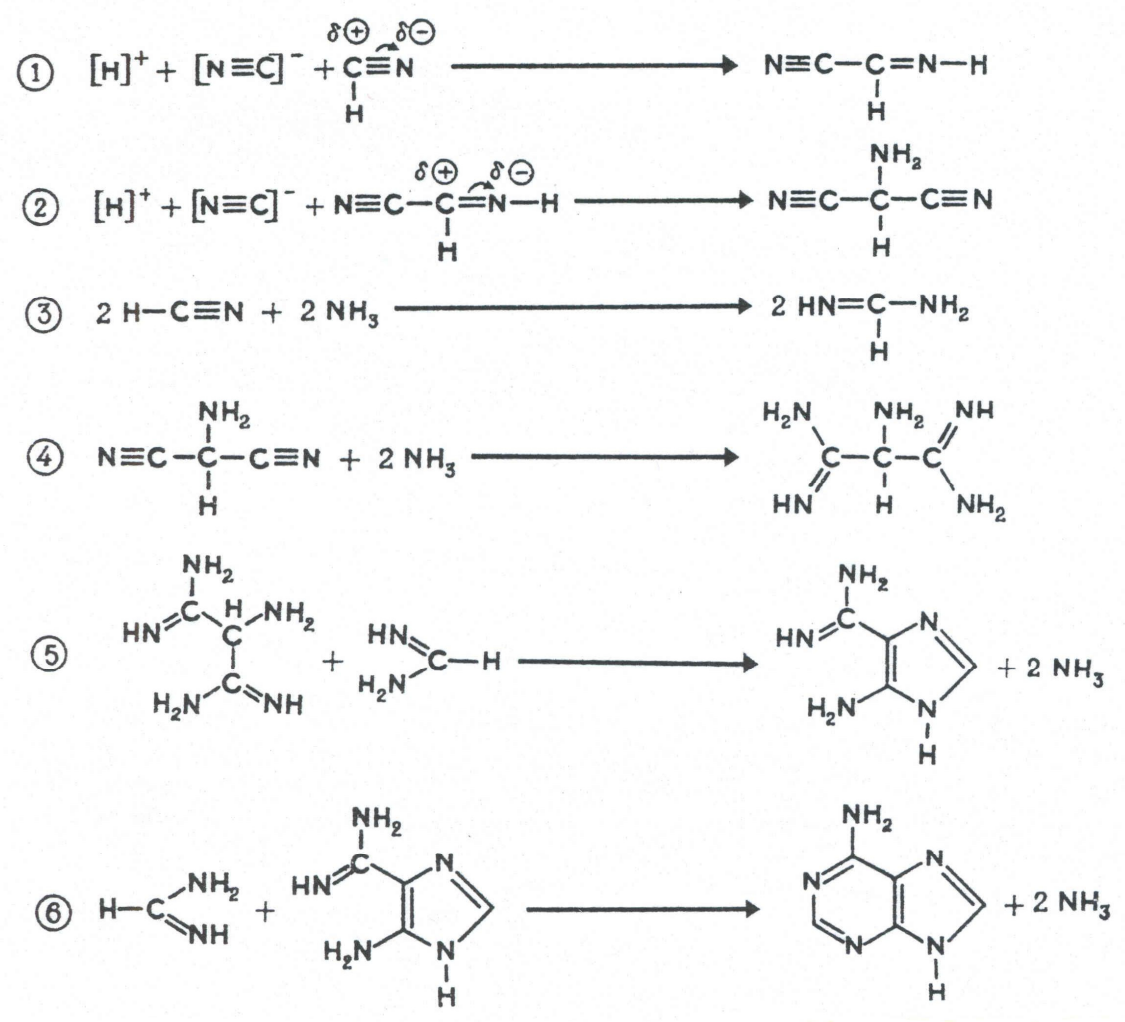

b)

Figure 11: Prospective mechanisms of thermal $\left(+95{ }^{0} \mathrm{C}\right)$ synthesis of purines in aqueous solutions: $\left.a\right)-$ synthesis of hypoxanthine, adenine, guanine and xanthine from 4-aminoimidazole-5-carboxamidine, 4-aminoimidazole-5carboxamide, water, $\mathrm{NH}_{3}$, formamidine and urea; $b$ ) - synthesis of adenine from $\mathrm{NH}_{3}$ and $\mathrm{HCN}$ (total reaction: $5 \mathrm{HCN}=$ adenine $)$

Taking into account the resent data (Ignatov \& Mosin, 2014; Ignatov \& Mosin, 2015) it may be concluded that the initial stage of evolution, apparently, was connected with the formation at high temperature the mixtures of amino acids and nitrogenous substances - analogues of nucleic acids. Such synthesis is possible in aqueous solutions under thermal conditions in the presence of $\mathrm{H}_{3} \mathrm{PO}_{4}$. The next stage is the polycondensation of amino acids into thermal proteinoids at temperatures $+65 \ldots+95{ }^{0} \mathrm{C}$. After that stage in a mix of thermal proteinoids in hot water solutions were formed the membrane like structures. The first living structures were most probably formed in warm and hot mineral water with more bicarbonate and metal ions ( $\mathrm{Na}, \mathrm{Ca}, \mathrm{Mg}, \mathrm{Zn}, \mathrm{K}$, etc.). The role of metal ions in metabolism consists in their using as catalysts of various metabolic reactions, while the metal complexes with organic molecules activate the organic molecules and organize the biochemical reactions. By activating it should be understood the polarization (stabilization of negative charges), and organization means the strict spatial arrangement of molecules or ions involved in the reaction. Therefore, the most important function of the metal complexes consists in strengthening the role of the systems of spatial codes toward the ways of chemical evolution.

\section{Conclusion}

The experimental data indicate that origination of life and living matter depends on physical-chemical properties of water and external factors - temperatures, $\mathrm{pH}$, electric discharges and isotopic composition. Hot mineral alkaline water interacting with $\mathrm{CaCO}_{3}$ is most closed to these conditions. Next in line with regard to its quality is seawater. For chemical reactions of dehydration-condensation to occur in hot mineral water, water is required to be alkaline with $\mathrm{pH}$ range 9-11. In warm and hot mineral waters the local maximums in IR-spectra from 8 to 14 $\mu \mathrm{m}$ were more expressed in comparison with the local maximums measured in the same water samples with lower temperature. The content of deuterium in hot mineral water may be increased due to the physical chemical processes of the deuterium accumulation as solar radiation, volcanic geothermal processes and electric discharges in the atmosphere. These natural processes could lead to the enrichment of the hydrosphere by deuterium in the form of HDO which evaporates more slowly than $\mathrm{H}_{2} \mathrm{O}$, and condenses faster. We had a 
perspective selection of chemoheterotrophic bacteria for our research as they are the microorganisms located on the lower stage of evolutionary development, and quickly adapt to changing environmental factors. The taxonomy of a Gram-positive chemoheterotrophic bacterium Bacillus subtilis and its resistance to deuterium was also analyzed on an evolutionary level taking into account the hydrological conditions of primodial hydrosphere and the presence of HDO, as well as the qualitative and quantitative composition of the cellular protein, amino acids and carbohydrates on media with maximum deuterium content. It was demonstrated on the example of chemoheterotrophic bacteria that first heterotrophic microorganisms might have been originated in hot mineral water at $\mathrm{t}=+65-95{ }^{0} \mathrm{C}$ and $\mathrm{pH}=9-11$ that is more suitable for maintenance and origin of life than other analyzed water samples.

\section{Acknowledgements}

Authors wish to thank Dr. Kristina Chakarova from Bulgarian Academy of Sciences (Sofia, Bulgaria) for registering the IR-spectra.

\section{References}

Abelson, P. (1966) Chemical events on the "primitive" earth, Proc. Natl. Acad. Sci. U.S. 55:1365-1372.

Baleux, B. (1977) A Computer study of the evolution of aerobic heterotrophic bacterial populations in sewage and river waters, Microbial Ecology, 4(1):53-65.

Bild, W., Nastasa, V., \& Haulica, I. (2004) In vivo and in vitro research on the biological effects of deuteriumdepleted water: influence of deuterium-depleted water on cultured cell growth, Rom J. Physiol., (41)1-2:53-67.

Bohinski, R.C. (1983) Modern Concepts in Biochemistry. Boston, London, Sydney, Toronto, Allyn \& Bacon Inc., Newton, Massachusetts, 378 p.

Calvin, M. (1969) Chemical Evolution, Oxford: Clarendon, 278 p.

Caetano-Anolles G, Kim HS, Mittenthal JE (2007). The origin of modern metabolic networks inferred from phylogenomic analysis of protein architecture. Proc Natl Acad Sci USA 104(22): 9358-63. DOI:10.1073/pnas.0701214104. PMID 17517598.

Cleland, W.N., O'Leary, M.H., \& Northrop, D.D., eds. (1976) Isotope effects on enzyme-catalyzed reactions. Baltimore, London, Tokyo: University Park Press, 303 p.

Crespi, H.L. (1989) Fully deuterated microorganisms: tools in magnetic resonance and neutron scattering. in: Synthesis and Applications of Isotopically Labeled Compounds, Proceedings of an International Symposium. (Baillie T, Jones J.R eds.), Amsterdam: Elsevier, 2:329-332.

Daboll, H.F., Crespi, H.L., \& Katz, J.J. (1962) Mass cultivation of algae in pure heavy water, Biotechnology and Bioengineering, 4(2): 281-297.

Ebenhöh O, Heinrich R (2001). Evolutionary optimization of metabolic pathways. Theoretical reconstruction of the stoichiometry of ATP and NADH producing systems. Bull Math Biol 63(1): 21-55. DOI: 10.1006/bulm.2000.0197. PMID 11146883.

Fox, S.W. \& Krampitz, G. (1964) Catalytic decomposition of glucose in aqueous solution by thermal proteinoids. Nature, 203: 1362-1364.

Fox, S.W. \& Wang, C.T. (1968) Melanocytestimulating hormone: Activity in thermal polymers of alpha-ammo acids. Science, 160: 547-548.

Harada, I. \& Fox, S.W. (1964) Thermal synthesis of natural ammo-acids from a postulated primitive terrestrial atmosphere. Nature, 201: 335-336.

Ignatov, I. (2010) Which water is optimal for the origin (generation) of life? Euromedica, Hanover, $35 \mathrm{p}$.

Ignatov, I. (2012) Origin of life and living matter in hot mineral water, Conference on the Physics, Chemistry and Biology of Water, Vermont Photonics, USA, 67 p.

Ignatov, I., \& Mosin, O.V. (2012) Isotopic composition of water and its temperature in modeling of primordial hydrosphere experiments, VIII Intern. Conference Perspectives of the Development of Science and Technique, Biochemistry and Biophysics, 15: 41-49.

Ignatov, I. \& Mosin, O.V. (2013a) Isotopic composition of water and its temperature in the evolutionary origin of life and living matter. Naukovedenie, 1(14): 1-16 [in Russian] [Online] Available: URL: http://naukovedenie.ru/PDF/42tvn113.pdf (February 13, 2013).

Ignatov, I. \& Mosin, O.V. (2013b) Possible processes for origin of life and living matter with modeling of physiological processes of bacterium Basillus subtilis as model system in heavy water. Journal of Natural Sciences Research, 3(9): 65-76.

Ignatov, I. \& Mosin, O.V. (2013c) Modeling of possible processes for origin of life and living matter in hot mineral and seawater with deuterium. Journal of Environment and Earth Science, 3(14): 103-118.

Ignatov, I. \& Mosin, O.V. (2014). Modeling of Possible Conditions for Origin of First Organic Forms in hot Mineral Water. European Journal of Molecular Biotechnology 5(3): 131-148. 
Ignatov I., Mosin, O.V. (2015) Origin of life and living matter in hot mineral water. Advances in Physics Theories and Applications. 39: 1-22.

Keller M.A., Ralser M., Turchyn A.V. (2014). Non-enzymatic glycolysis and pentose phosphate pathway-like reactions in a plausible Archean ocean. Mol. Syst. Biol. 10: 725.doi:10.1002/msb.20145228. PMID 24771084.

Koch A (1998). How did bacteria come to be? Adv Microb Physiol 40:353-99. DOI: $10.1016 / \mathrm{S} 0065-$ 2911(08)60135-6. PMID 9889982.

Kurihara, K., Tamura, M., Shohda, K., Toyota, T., Suzuki, K., \& Sugawara, T. (2011) Self-Reproduction of supramolecular giant vesicles combined with the amplification of encapsulated DNA, Nature Chemistry, 4(10):775-781.

Kushner, D.J., Baker, A., \& Dunstall, T.G. (1999) Pharmacological uses and perspectives of heavy water and deuterated compounds, Can. J. Physiol. Pharmacol., 77(2):79-88.

Lamprecht, I. Schroeter, D. \& Paweletz, N. (1989) Disorganization of mitosis in HeLa cells by deuterium oxide, European journal of cell biology, 50(2): 360-369.

Lis, G., Wassenaar, L.I., \& Hendry, M.J. (2008) High-precision laser spectroscopy D/H and ${ }^{18} \mathrm{O} /{ }^{16} \mathrm{O}$ measurements of microliter natural water samples, Anal. Chem., 80(1):287-293.

Lobishev, V.N., \& Kalinichenko, L.P. (1978) Isotopic Effects of $\mathrm{D}_{2} \mathrm{O}$ in Biological Systems. Moscow: Nauka, 215 p. [in Russian].

Mathews, C.N., \& Moser, R. (1968) Peptide synthesis from hydrogen-cyanide and water, Nature, 215: 12301234.

Meléndez-Hevia E, Waddell T, Cascante M (1996). The puzzle of the Krebs citric acid cycle: assembling the pieces of chemically feasible reactions, and opportunism in the design of metabolic pathways during evolution. $J$ Mol Evol 43(3): 293-303. DOI:10.1007/BF02338838. PMID 8703096.

Miller, S.L. (1953) A production of amino acids under possible primitive Earth conditions, Science, 117(3046): 528-529.

Mosin, O.V. (1996) Studying of methods of biotechnological preparation of proteins, amino acids and nucleosides, labeled with stable isotopes ${ }^{2} \mathrm{H},{ }^{13} \mathrm{C}$ and ${ }^{15} \mathrm{~N}$ with high levels of isotopic enrichment: autoref. disser. thesis PhD: Moscow, M.V. Lomonosov State Academy of Fine Chemical Technology, 26 p.

Mosin, O.V, Skladnev, D.A, \& Shvets, V.I. (1998) Biosynthesis of ${ }^{2}$ H-labeled phenylalanine by a new methylotrophic mutant Brevibacterium methylicum, Biosci Biotechnol Biochem., 62(2):225-229.

Mosin, O.V., Skladnev, D.A., \& Shvets, V.I. (1999) Biosynthesis of ${ }^{2}$ H-labelled inosine by bacterium Bacillus subtilis, Izv. RAN. Ser. biologicheskaja., 4:396-402 [in Russian].

Mosin, O.V., Skladnev, D.A., \& Shvets, V.I. (2000) Studying of adaptation to heavy water, Biotechnologija, 10:16-23 [in Russian].

Mosin, O.V, \& Ignatov I. (2012a) Isotope effects of deuterium in bacterial and microalgae cells at growth on heavy water $\left(\mathrm{D}_{2} \mathrm{O}\right)$, Water: Chemistry and Ecology, 3:83-94 [in Russian].

Mosin, O.V. \& Ignatov, I. (2012b) Studying of isotopic effects of heavy water in biological systems on example of prokaryotic and eukaryotic cells. Biomedicine, Moscow, 1(1-3): 31-50 [in Russian].

Mosin O., Ignatov I. (2015) Metabolism, Physiology and Biotechnological Applications of Halobacteria. European Journal of Molecular Biotechnology 8(2): 88-102.

Mosin, O.V., Ignatov, I., Skladnev, D.A. \& Shvets, V.I. (2013a) A strain of Gram-positive chemoheterotrophic bacterium Basillus subtilis - producer of $\left[{ }^{2} \mathrm{H}\right]$ riboxine. Drug development \& registration, 4(5): 110-119 [in Russian].

Mosin, O.V. \& Ignatov, I. (2013a) Microbiological synthesis of ${ }^{2} \mathrm{H}$-labeled phenylalanine, alanine, valine, and leucine/isoleucine with different degrees of deuterium enrichment by the Gram-positive facultative methylotrophic bacterium Brevibacterium methylicum. International Journal of Biomedicine, 3(2), 132-138.

Mosin, O.V., \& I. Ignatov, I. (2013b) Microbiological synthesis of ${ }^{2} \mathrm{H}$-labeled phenylalanine, alanine, valine, and leucine/isoleucine with different degrees of deuterium enrichment by the Gram-positive facultative methylotrophic bacterium Brevibacterium methylicum, International Journal of BioMedicine, 3(2): 132-138.

Mosin, O.V. \& Ignatov, I. (2013a) Studying the biosynthesis of ${ }^{2} \mathrm{H}$-labeled inosine by a Gram-positive chemoheterotrofic bacterium Bacillus subtilis B-3157 on heavy water $\left({ }^{2} \mathrm{H}_{2} \mathrm{O}\right)$ medium. Chemical and Process Engineering Research, 15: 32-45.

Mosin O., \& Ignatov I. (2014) Evolution, Metabolism and Biotechnological Usage of Methylotrophic Microorganisms. European Journal of Molecular Biotechnology 5(3): 104-19.

Mosin, O.V., Shvets, V.I., Skladnev, D.A., \& Ignatov, I. (2012) Studying of microbic synthesis of deuterium labeled L-phenylalanine by methylotrophic bacterium Brevibacterium Methylicum on media with different content of heavy water, Russian Journal of Biopharmaceuticals, 4 (1): 11-22 [in Russian].

Mosin, O.V., Shvez, V.I, Skladnev, D.A., \& Ignatov, I. (2013) Microbiological synthesis of $\left[{ }^{2} H\right]$ inosine with high degree of isotopic enrichment by Gram-positive chemoheterotrophic bacterium Bacillus subtilis, Applied Biochemistry and Microbiology, 49 (3): 255-266. 
Nakashima, T. (1987) Metabolism of proteinoid microspheres / Ed. T. Nakashima. In: Origins of life and evolution of biospheres, 20(3-4), pp. 269-277.

Ouzounis C, Kyrpides N (1996). The emergence of major cellular processes in evolution. FEBS Lett 390(2): 119-23. DOI:10.1016/0014-5793(96)00631-X. PMID 8706840.

Ponsa, M.L., Quitte G.., Fujii, T. et al. (2011) Early archean serpentine mud volcanoes at Isua, Greenland, as a niche for early life. Proc. Natl. Acad. Sci. U.S., 108: 17639-17643.

Romano A, Conway T (1996). Evolution of carbohydrate metabolic pathways. Res Microbiol 147(6-7): 448-55. DOI:10.1016/0923-2508(96)83998-2. PMID 9084754.

Schirber, M. (2010) First fossil-makers in hot water. Astrobiology magazine [Online] Available: URL: http://www.astrobio.net/exclusive/3418/first-fossil-makers-in-hot-water (January 3, 2010).

Sinyak, Y., Grigoriev, A., Gaydadimov, V., Gurieva, T., Levinskih, M., \& Pokrovskii, B. (2003) Deuterium-free water in complex life-support systems of long-term space missions, Acta Astronautica, 52:575-577.

Schmidt S, Sunyaev S, Bork P, Dandekar T (2003). Metabolites: a helping hand for pathway evolution?. Trends Biochem Sci 28(6): 336-41. DOI:10.1016/S0968-0004(03)00114-2. PMID 12826406.

Smith E, Morowitz H (2004). Universality in intermeditary metabolism. Proc Natl Acad Sci USA 101(36): 13168-73. DOI:10.1073/pnas.0404922101. PMID 15340153.

Stanier R.Y., Adelberg E.A., Ingraham J.L. The Microbial World. (4th ed.). New Jersey: Prentice-Hall Inc. pp. 190-192.

Stryer, L. (1995). Glycolysis. In: Biochemistry. (4th ed.). New York: W.H. Freeman and Company. pp. $483-508$. Sugawara, T. (2011) Self-reproduction of supramolecular giant vesicles combined with the amplification of encapsulated DNA. Nature Chemistry, 1127: 775-780.

Török, G., Csík, M., Pintér, A. et al. (2000) Effects of different deuterium concentrations of the media on the bacterial growth and mutagenesis. Egészségtudomány/Health Science, 44: 331-338.

Thomson, J.F. (1960) Physiological effects of $\mathrm{D}_{2} \mathrm{O}$ in mammals. Deuterium Isotope Effects in Chemistry and Biology, Annals of the New York Academy of Sciences, 84: 736-744.

Vertes, A. (2003) Physiological effects of heavy water. Elements and isotopes: formation, transformation, distribution. - Dordrecht: Kluwer Acad. Publ. 112 p.

Ward, D. (2010) First fossil-makers in hot water. Astrobiology magazine. [Online] Available: URL: http://www.astrobio.net/exclusive/3418/first-fossil-makers-in-hot-water (3 January 2010). 
The IISTE is a pioneer in the Open-Access hosting service and academic event management. The aim of the firm is Accelerating Global Knowledge Sharing.

More information about the firm can be found on the homepage:

http://www.iiste.org

\section{CALL FOR JOURNAL PAPERS}

There are more than 30 peer-reviewed academic journals hosted under the hosting platform.

Prospective authors of journals can find the submission instruction on the following page: http://www.iiste.org/journals/ All the journals articles are available online to the readers all over the world without financial, legal, or technical barriers other than those inseparable from gaining access to the internet itself. Paper version of the journals is also available upon request of readers and authors.

\section{MORE RESOURCES}

Book publication information: http://www.iiste.org/book/

Academic conference: http://www.iiste.org/conference/upcoming-conferences-call-for-paper/

\section{IISTE Knowledge Sharing Partners}

EBSCO, Index Copernicus, Ulrich's Periodicals Directory, JournalTOCS, PKP Open Archives Harvester, Bielefeld Academic Search Engine, Elektronische Zeitschriftenbibliothek EZB, Open J-Gate, OCLC WorldCat, Universe Digtial Library, NewJour, Google Scholar

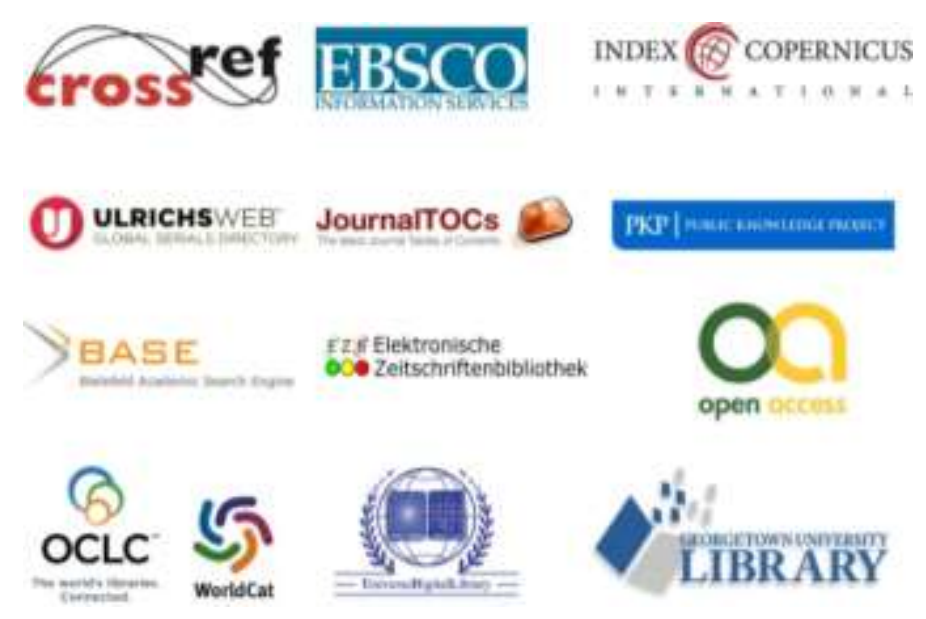

